\title{
ORNL Parking Structure Mitigation Report Oak Ridge National Laboratory
}

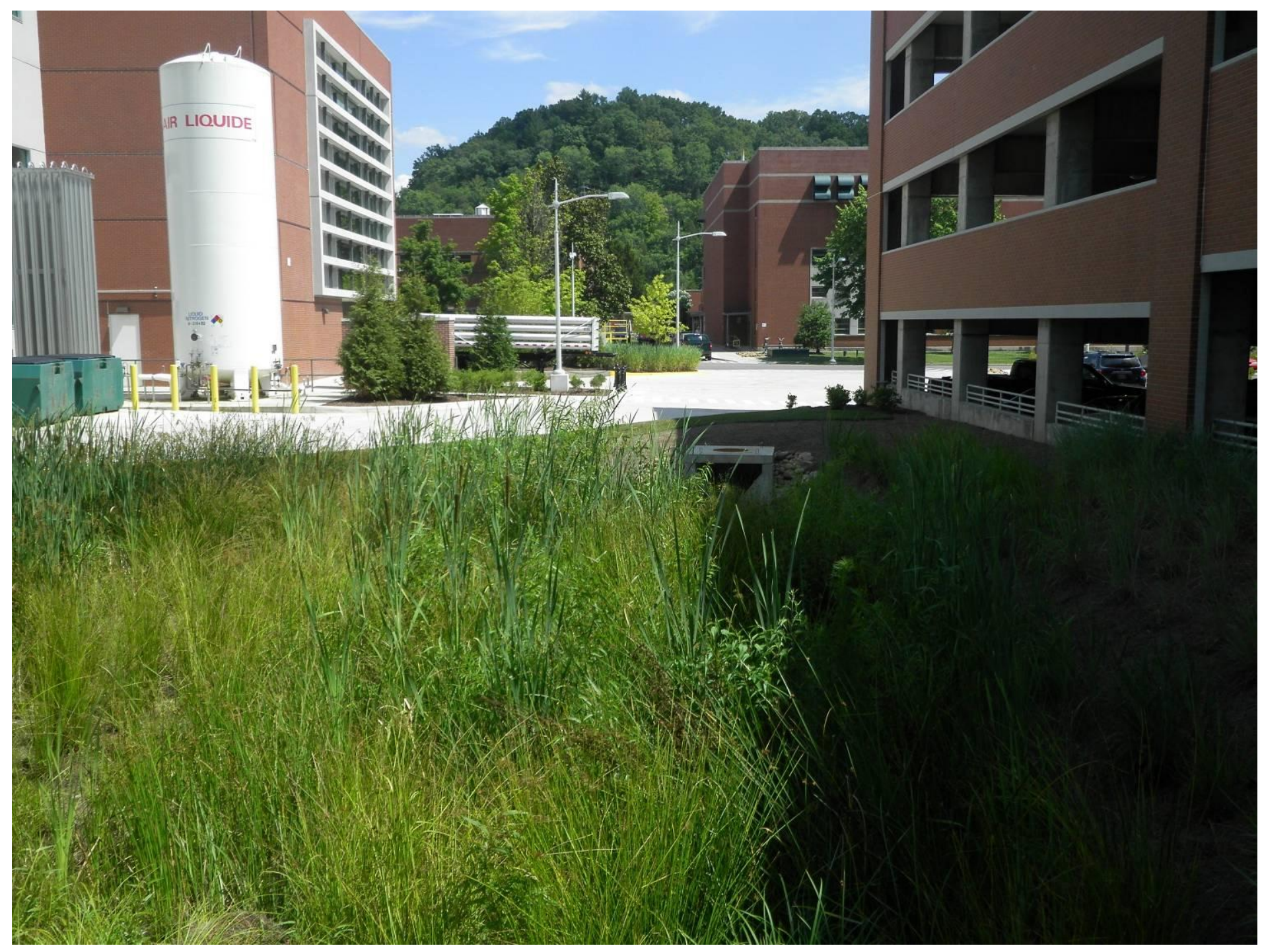

N. R. Giffen

M.G. Ryon

R. T. Jett

J. G. Smith

A. M. Haines

September 2012 


\section{ORNL PARKING STRUCTURE MITIGATION REPORT OAK RIDGE NATIONAL LABORATORY}

\subsection{INTRODUCTION}

Approximately 200 feet of an unnamed tributary to Fifth Creek and approximately 0.08 acres of wetland were impacted as a result of the construction of a new parking structure at Oak Ridge National Laboratory (ORNL) that was completed in Fiscal Year 2011. Compensatory mitigation, as per requirements set by the Tennessee Department of Environment and Conservation (TDEC), included the following:

- On-site expansion of an existing wetland (P2) by 0.04 acres adjacent to the new ORNL parking structure.

- On-site enhancement and preservation of approximately 800 feet of First Creek (between White Oak Avenue and West End Circle), 400 feet of White Oak Creek (at Building 4515, the High Temperature Materials Laboratory), and associated riparian zones.

Monitoring of restored or created mitigation sites for five years is a conventional requirement of TDEC's wetland-mitigation Aquatic Resource Alteration Permits (ARAPs) as required by Section 401 of the Clean Water Act (CWA) and is consistent with current science regarding the minimum length of time required for the stabilization of biological communities (Niemi, et al. 1990). The rates of recovery of wetland and stream restorations have been shown to be highly variable on the Oak Ridge Reservation (ORR); by monitoring the site, modifications can be made in a timely manner to best achieve restoration goals. For wetland mitigations, the restoration site must satisfy jurisdictional wetland requirements after five years.

This report summarizes the 2012 results of habitat assessments and vegetation surveys completed at the subject sites, representing the second year of study. The evaluation was based on data collected in the field directly associated with this task, as well as data collected as part of the ORNL Environmental Sciences Division (ESD) Biological Monitoring and Abatement Program (BMAP). BMAP data is a valuable resource in evaluating the success of stream restorations, when available.

\subsection{METHODS}

\subsection{ORNL Parking Structure Wetland (P2)}

Vegetation parameters were measured at the ORNL parking structure wetland (P2) in May-June 2012, approximately one year after mitigation. Parameters were measured in a series of $1 / 2$ meter plots across the site. Percent cover by species was measured for each plot. Information was also taken on any fauna present on the site at the time of the survey.

\subsection{First Creek and White Oak Creek}

Stream habitat assessments were conducted at both First Creek (July 2012) and White Oak Creek (June 2012) reaches using Habitat Assessment Data Sheets found in the Tennessee Mitigation Guidelines. Metrics evaluated at both sites included epifaunal substrate, embeddedness (amount 
of silt, etc, between rocks), velocity/depth regime, sediment deposition, channel flow, frequency of riffles, bank stability, and vegetative cover. These parameters were measured using rapid bioassessment protocols for use in wadeable streams and rivers (Barbour et al. 1999).

Quantitative habitat measurements recorded for both the First Creek site (July 2012) and the White Oak Creek site (June 2012) represent post-mitigation habitat conditions. Pre-mitigation conditions for First Creek are discussed qualitatively from information contained in previous reports (Ryon and Quarles 2008). The assessment of White Oak Creek pre-mitigation habitat conditions are discussed in detail in the ORNL Parking Structure Mitigation Report, Oak Ridge National Laboratory (Giffen, Ryon and Jett 2011).

Riparian zone vegetation surveys were conducted by establishing 10x5 meter plots approximately 10 meters apart (First Creek - east bank, White Oak Creek - north and south banks). A total of 11 plots were established at First Creek and 13 plots were established at White Oak Creek. For each plot the following parameters were measured; trees $(\geq 3$ inches diameter at breast height ) - measured, shrub stems ( $<3$ inches diameter at breast height $)$ - counted, percent groundcover, percent canopy cover, canopy height, vegetation overhang $(\mathrm{cm})$ for each stream bank.

Fish and benthic community monitoring results were evaluated as an indicator of whether or not the stream sections are functioning as suitable habitat for in-stream organisms.

Benthic macroinvertebrate community data was gathered at First Creek (July 6, 2012) and White Oak Creek (July 6, 2012) using an EPA approved rapid qualitative assessment technique. At each site seven aquatic habitats were identified and sampled for aquatic macroinvertebrates; riffles, leaf packs, woody debris, rocks, root wads, aquatic vegetation, and in-stream sediment deposition. These habitats were located within 100 meters upstream and downstream of the sampling site established along each reach. When habitats were missing from the site they were not sampled. For each habitat a twelve inch rim D-Net with 500 micron nylon netting was used to collect samples. Each sample was sorted immediately at the site using forceps and a white sorting tray for 15 minutes. After 15 minutes of sorting all taxonomic identification was recorded on a data sheet and another habitat was sampled and sorted. After all habitats were sampled and recorded, the total number of families of insects was tallied to determine number of families represented by the orders Ephemeroptera, Plecoptera, and Trichoptera.

BMAP fish survey data used for evaluation of First Creek was from close proximity to the subject reach. The fish community data used for evaluation of the White Oak Creek site was from data taken during routine BMAP surveys within the subject reach. The fish communities within these reaches were monitored using a multiple pass removal estimate method (Ryon 2011). The sample sites were isolated by block-nets, multiple passes were made using backpack or barge electrofishers and all stunned fish were collected. Fish were identified to species, measured for length and weight, and returned to the site. Sample numbers were standardized to sample reach by using the surface area of the site and resulting data were analyzed using a computer program to estimate population densities and biomass. Similar monitoring is conducted at other sites and data are available for comparisons. 


\subsection{RESULTS}

\subsection{ORNL Parking Structure Wetland (P2)}

This section contains vegetation sampling results and fauna recorded in the P2 wetland after mitigation.

Vegetation cover measurements were taken from ten $1 / 2$ meter square plots for this wetland in May 2012. Groundcover averaged $>70 \%$ across all plots, significantly more than the $<28 \%$ average groundcover recorded in 2011 prior to mitigation. The vegetation in the plots consisted mostly of herbaceous wetland species, including softstem bulrush (Schoenoplectus tabernaemontani), soft rush (Juncus effusus) and Frank's sedge (Carex frankii). Small black willows (Salix nigra) and cattails (Typha latifolia) were noted growing in patches within the wetland.

A variety of fauna was observed on this site during the summer of 2012. During the plant survey in May, Cope's gray treefrog (Hyla chrysoscelis) eggs were discovered in a shallow pool in the wetland. Song sparrows (Melospiza melodia) were both seen and heard at the site, while barn swallows (Hirundo rustica) were noted foraging for insects over the wetland. Pond snails (Physella sp.) were found in abundance within the shallow pools at the western end of the wetland, along with a number of water beetles (Agabetes sp.) and dragonfly larvae (Aeshna sp.). Along the edges of the wetland, a small number of fragile forktails (Ischnura posita) were noted, as well as an eastern cottontail (Sylvilagus floridanus).

In an evening fauna survey in June, 2012, eastern narrow-mouthed toads (Gastrophryne carolinensis) were heard at the site, and several fireflies (Family Lampyridae) were present. A white-tailed deer (Odocoileus virginianus) was also recorded near the edge of the wetland.

Overall, a higher diversity of fauna was noted using the wetland in 2012 than in 2011.

Mitigation planting was completed in the wetland in June 2011. A list of species planted in the wetland is contained in Table 1. During an evaluation of known planted species during the 2012 survey, excellent coverage of soft rush was particularly noticeable. Only small patches of woolgrass (Scirpus cyperinus) were noted in the wetland. Square-sided spikerush (Eleocharus quadrangulata) was not recorded during the 2012 survey. However, chairmaker's bulrush (Schoenoplectus americanus) was found to be fairly prevalent in the planting zone. It is not clear if this species is a volunteer or may have come in with the mitigation plantings. In any case, this species is contributing to the excellent overall vegetation coverage on the site. Both cardinal flower (Lobelia cardinalis) and southern blueflag iris (Iris virginica) were noted growing along the wetland fringe. No dead plants were found during the survey. 
Table 1. List of Species Planted at the P2 Wetland, June 2011.

\begin{tabular}{|l|l|l|c|}
\hline Common Name & Scientific Name & Indicator Status $^{\mathbf{1}}$ & Number of Plugs \\
\hline Soft Rush & Juncus effusus & FACW & 350 \\
\hline Wool-grass & Scirpus cyperinus & OBL & 450 \\
\hline Square-sided Spikerush & Eleocharis quadrangulata & OBL & 550 \\
\hline Cardinal flower & Lobelia cardinalis & FACW & 200 \\
\hline Southern Blueflag Iris & Iris virginica & OBL & 200 \\
\hline & & & Total \\
\hline
\end{tabular}

${ }^{1}$ Obligate Wetland $(\mathrm{OBL})=$ Occur almost always (estimated probability $>99 \%$ ) under natural conditions in wetlands. Facultative Wetland $($ FACW) $=$ Usually occur in wetlands (estimated probability 67\%-99\%), but occasionally found in non-wetlands.

Figure 1 shows photographs comparing the condition of the P2 wetland between 2011 (soon after mitigation) and 2012. The wetland continues to support good vegetation coverage. 
Figure 1. Photographs of P2 Wetland in 2011 and 2012.

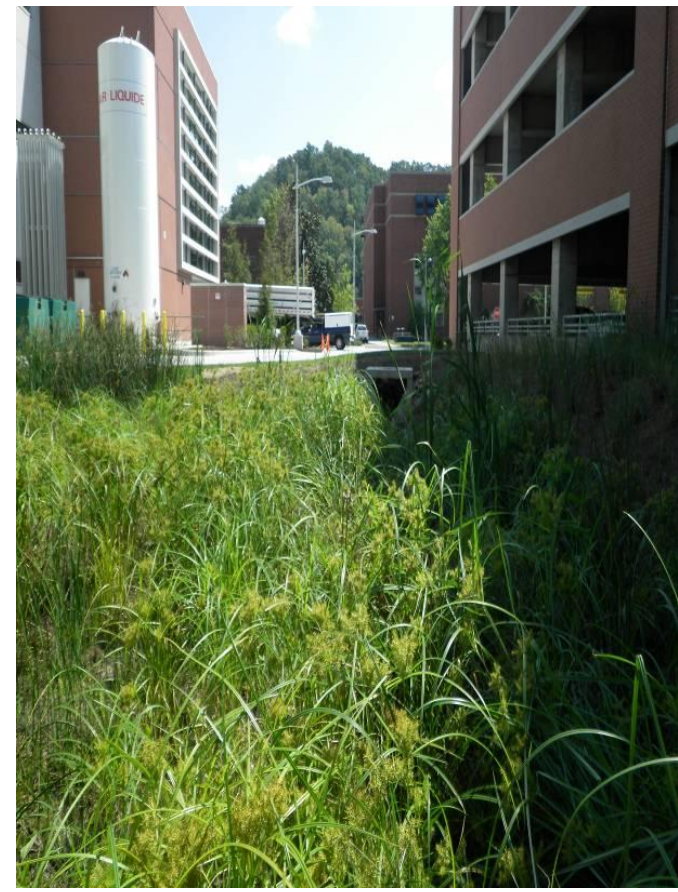

After Mitigation (September 12, 2011)

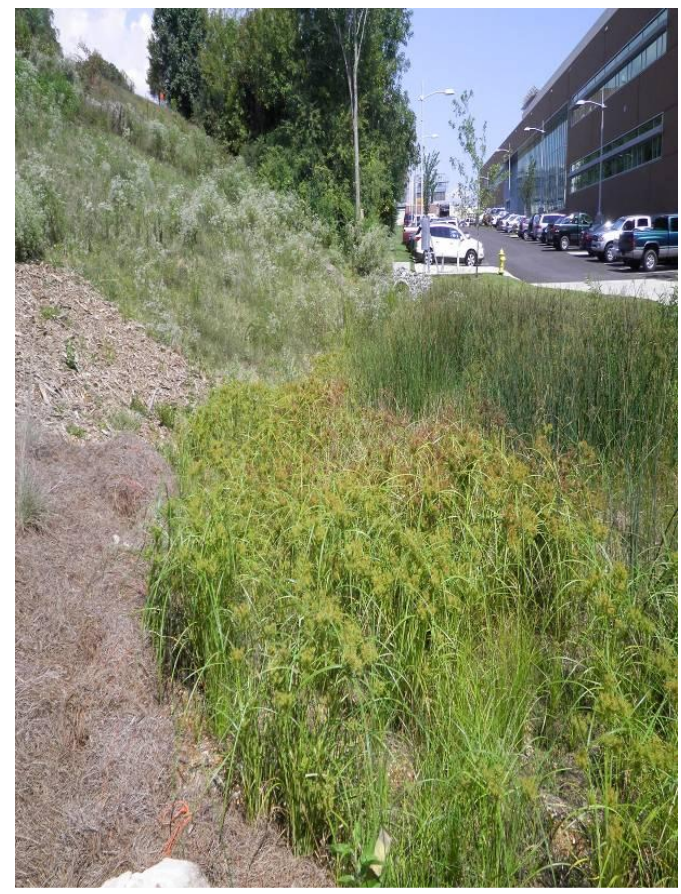

After Mitigation (September 12, 2011)

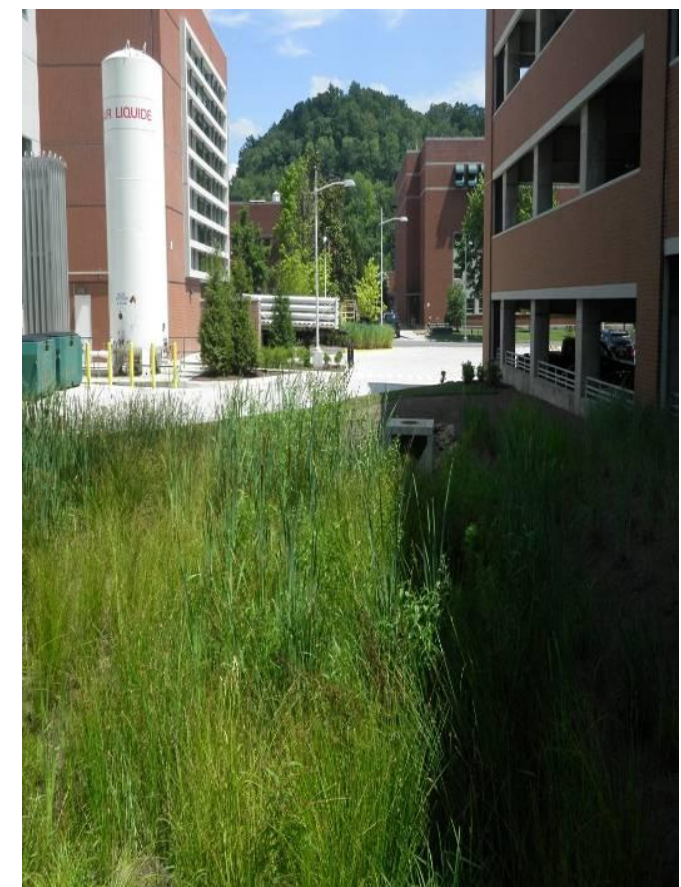

Current Appearance (June 12, 2012)

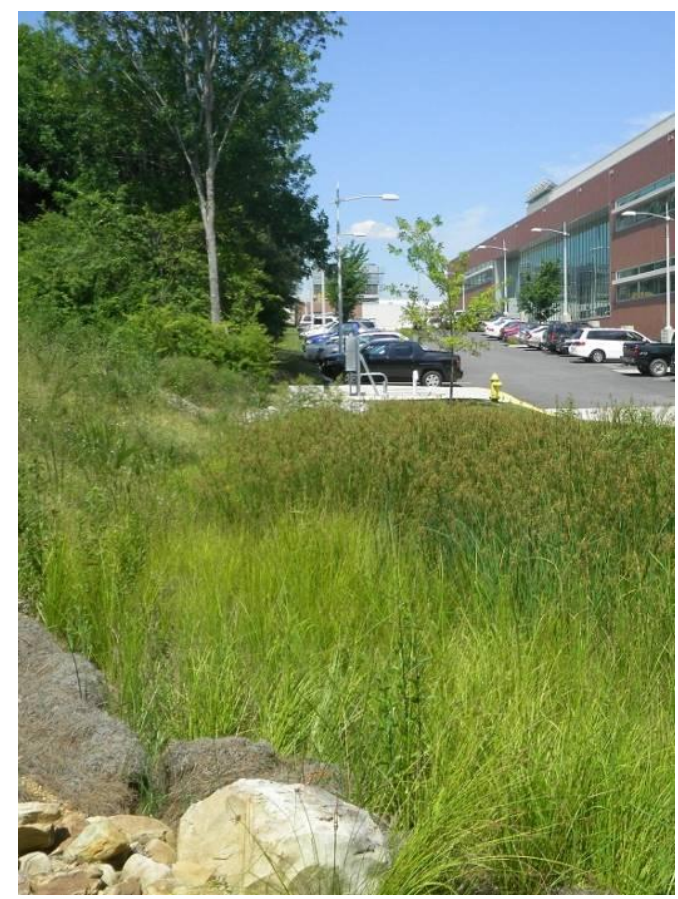

Current Appearance (June 12, 2012) 


\subsection{Habitat Assessments - First Creek and White Oak Creek Reaches}

The streams were rated using the 10 main categories on the Habitat Assessment Data Sheet, with a grading scale ranging from 0 to 20. An example data sheet is contained in Appendix A. A brief description of the 10 habitat measurements and their significance is provided below (Barbour et al. 1999):

1. Epifaunal Substrate/Available Cover - This is a measurement of the relative quantity and variety of natural structures in the stream, such as cobble (riffles), large rocks, fallen trees, logs and branches, and undercut banks, available as refugia, feeding, or sites for spawning and nursery functions for aquatic macrofauna. A wide variety and/or abundance of submerged structures in the stream provides macroinvertebrates and fish with a large number of niches, thus increasing habitat diversity.

2. Embeddedness - This measurement refers to the extent to which rocks (gravel, cobble and boulders) and snags are covered and sunken into the silt, sand, or mud or the stream bottom. Generally as rocks become embedded the surface area available to macroinvertebrates and fish (shelter, spawning and egg incubation) is decreased. Embeddedness is the result of large-scale sediment movement and deposition, and is a parameter evaluated in the riffles and runs of high gradient streams.

3. Velocity/Depth Regime - Patterns of velocity and depth are included for high-gradient streams under this parameter as an important feature of habitat diversity. The occurrence of the 4 patterns (slow deep, slow-shallow, fast deep and fast-shallow) relates to the stream's ability to provide and maintain a stable aquatic environment.

4. Sediment Deposition - Sediment deposition may result in the formation of islands, bars or shoals, or result in the filling of runs and pools. High levels of sediment deposition is an indication of an unstable and continually changing environment that becomes unsuitable for many organisms.

5. Channel Flow Status - This is an important parameter because when water does not cover much of the streambed, the amount of suitable substrate for aquatic organisms is limited. In high-gradient streams, riffles and cobble substrate are exposed, thereby reducing the areas of good habitat.

6. Channel Alteration - This is a measure of the large scale changes in the shape of the stream channel, and degree of stream alteration as the result of diversion. These changes decrease the amount of natural habitats for fish, macroinvertebrates, and plants below that which would be expected for naturally meandering streams. Scouring is often associated with channel alteration.

7. Frequency of Riffles (or bends) - The frequency of riffles is a measure of heterogeneity in the stream. Riffles are a source of high quality habitat and diverse fauna and, therefore, an increased frequency of occurrence greatly enhances habitat diversity in the stream community. A high degree of sinuosity in a stream provides diverse habitat and fauna, and the stream is better able to handle surges when the stream fluctuates as a result of storm events. The absorption of this 
energy by bends protects the stream from excessive erosion and flooding, and provides refugia for benthic invertebrates and fish during such storm events.

8. Bank Stability (conditions of banks) - Signs of erosion typically include crumbling, unvegetated banks, exposed tree roots and exposed soil. Eroded banks indicate a problem of sediment movement and deposition, and suggest a scarcity of cover and organic input to streams.

9. Vegetative Protection (banks) - This parameter provides information on the ability of the bank to resist erosion as well as some additional information on the uptake of nutrients by the plants, the control of stream scouring and stream shading. Banks that have full, natural growth provide better quality fish and macroinvertebrate habitat over those without vegetative protection, or those shored up with concrete or riprap.

10. Riparian Vegetative Zone Width - The riparian vegetative zone serves as a buffer to pollutants entering the stream from runoff, controls erosion and provides habitat and nutrient input into the stream. A relatively undisturbed riparian zone supports a robust stream system. Encroachment of roads and other disturbances can result in degradation of the riparian zone.

The ratings for each of the above parameters were tallied for both streams to come up with an overall score, which was used to determine whether or not they were considered to be impaired. This represents the second year of assessment for the mitigated reach of First Creek and the first year of assessment post-mitigation for the White Oak Creek reach. The 2011 assessment of the White Oak Creek reach was prior to mitigation. Results are summarized below.

\subsubsection{First Creek Habitat Assessment}

First Creek habitat attributes for 2012 were virtually the same as those recorded in 2011 . The 2012 assessment is as follows:

1. Epifaunal Substrate/Available Cover - This reach of First Creek scored in the low optimal range for epifaunal substrate/available cover. It is estimated that approximately $70 \%$ of the substrate is favorable for epifaunal colonization and fish cover. This particular reach provides numerous riffles, undercut banks, cobble, larger rocks, falls and overhanging branches. The area is somewhat lacking in presence of logs and snags.

2. Embeddedness - This reach scored in the lower optimal range for embeddedness. This means that gravel, cobble and boulder particles are $0-25 \%$ surrounded by fine sediment. Gravel, cobble and boulder particles were $<25 \%$ surrounded by fine sediment for most of the length of the First Creek reach. The reach contained a variety of rock and cobble sizes with some good layering and crevices for cover.

3. Velocity/Depth Regime - The First Creek reach scored in the mid-optimal range for velocity/depth regime. This means that all 4 velocity/depth regimes (slow deep, slow-shallow, fast deep and fast-shallow) were present.

4. Sediment Deposition - The First Creek reach scored in the mid-optimal range for sediment deposition. This means that there is little or no enlargement of islands or point bars and less than 
$5 \%$ of the bottom is affected by sediment deposition. The reach contained no islands or bars. There was some channeling in areas that contained mats of water-purslane (Ludwigia palustris).

5. Channel Flow Status - The First Creek reach scored in the mid-optimal range for channel flow. This means that the water reaches the base of both lower banks, and a minimal amount of channel substrate is exposed. Good bank to bank flow was noted in most all locations along the First Creek reach, with no noticeable locations where this wasn't the case.

6. Channel Alteration - The First Creek reach scored in the mid-suboptimal range for channel alteration. This means that there is some channelization present. Modification of banks probably occurred with past development in the area (e.g., landscaping, roads).

7. Frequency of Riffles (or bends) - The First Creek reach scored in the mid-optimal range for frequency of riffles. This means that the frequency of riffles is relatively frequent. Riffles were very frequent along this reach, with a ratio of distance between riffles divided by stream width measured at approximately 2:1. The reach displayed a variety of habitats with some small falls into pools, larger rocks, and natural rock obstructions.

8. Bank Stability (conditions of banks) - The First Creek reach scored in the lower optimal range for bank stability, for both banks. This means that banks are stable where evidence of erosion or bank failure is absent or minimal, with little potential for future problems. This reach showed little to no evidence of erosion or bank failure.

9. Vegetative Protection (banks) - The First Creek reach scored in the lower optimal range for vegetative protection along both the left and right banks. The optimal characterization means that more than $90 \%$ of the stream bank surfaces are covered by vegetation. The First Creek reach showed vegetation coverage along most of its length, with no real evidence of disruption on either side.

10. Riparian Vegetative Zone Width - The First Creek reach scored in the mid marginal and poor ranges for riparian vegetative zone width. The right bank riparian zone scored lower than the left bank. A poor rating is given when width of the riparian zone is less than 6 meters wide due to human disturbance. The right side riparian zone is narrower and contains some native vegetation mixed with some invasives [(e.g., Johnson grass (Sorghum halepense)]. Quality riparian zone is very narrow (average $=5.5$ meters) on this side and is restricted by large areas of mowed turf, landscaped areas and parking lots. The left bank riparian zone (average $=11.5$ meters) fell into the marginal range, which is given when width of the riparian zone is 6-12 meters with evidence of human disturbance. The reach of this riparian zone is restricted in width by the presence of curbing and a paved parking area. The left side represents the mitigated side of the creek riparian zone and contains a mixture of native plants, wood chips and some turf grass areas. Areas closer to the curb had a more groomed landscaped look and areas closer to the creek contained thicker growth, with a number of previously planted and volunteer species. Some invasive plants [e.g., winter creeper (Euonymus fortunei)] are also present on the left side of the creek. Riparian zone width values were similar to those found in 2011 (left $=10.9 \mathrm{~m}$, right $=6.5 \mathrm{~m}$ ). Figure 2 shows both left and right side riparian zones, with comparisons between 2011 and 2012. Additional vegetation growth and coverage was noticeable between 2011 and 2012 for the mitigated east/left side. 
Table 2 shows individual ratings for each of the 10 main categories and the overall habitat assessment score for this First Creek reach. The overall rating given to this site places it well within the category of non-impaired for the 2012 evaluation, with the same score as that recorded in 2011. Figure 3 shows representative photos of certain habitat attributes along the First Creek reach.

Table 2. Habitat Assessment for First Creek Reach.

\begin{tabular}{|l|c|}
\hline PARAMETERS & $\mathbf{0 7 / 1 6 / 2 0 1 2}$ \\
\hline Epifaunal Substrate/Available Cover & 16 \\
\hline Embeddedness & 17 \\
\hline Velocity/depth regime & 18 \\
\hline Sediment deposition & 18 \\
\hline Channel flow status & 18 \\
\hline Channel alteration & 13 \\
\hline Frequency of Riffles & 18 \\
\hline Bank Stability - Left & 9 \\
\hline Bank Stability - Right & 9 \\
\hline Vegetative Protection - Left & 9 \\
\hline Vegetative Protection - Right & 9 \\
\hline Riparian Vegetative Zone Width - Left & 5 \\
\hline Riparian Vegetative Zone Width - Right & 2 \\
\hline \multicolumn{2}{|c|}{ Score (Goal $\geq \mathbf{1 3 1})$} \\
\hline Narrative Rating & Non-Impaired \\
\hline
\end{tabular}


Figure 2. First Creek Riparian Zones.

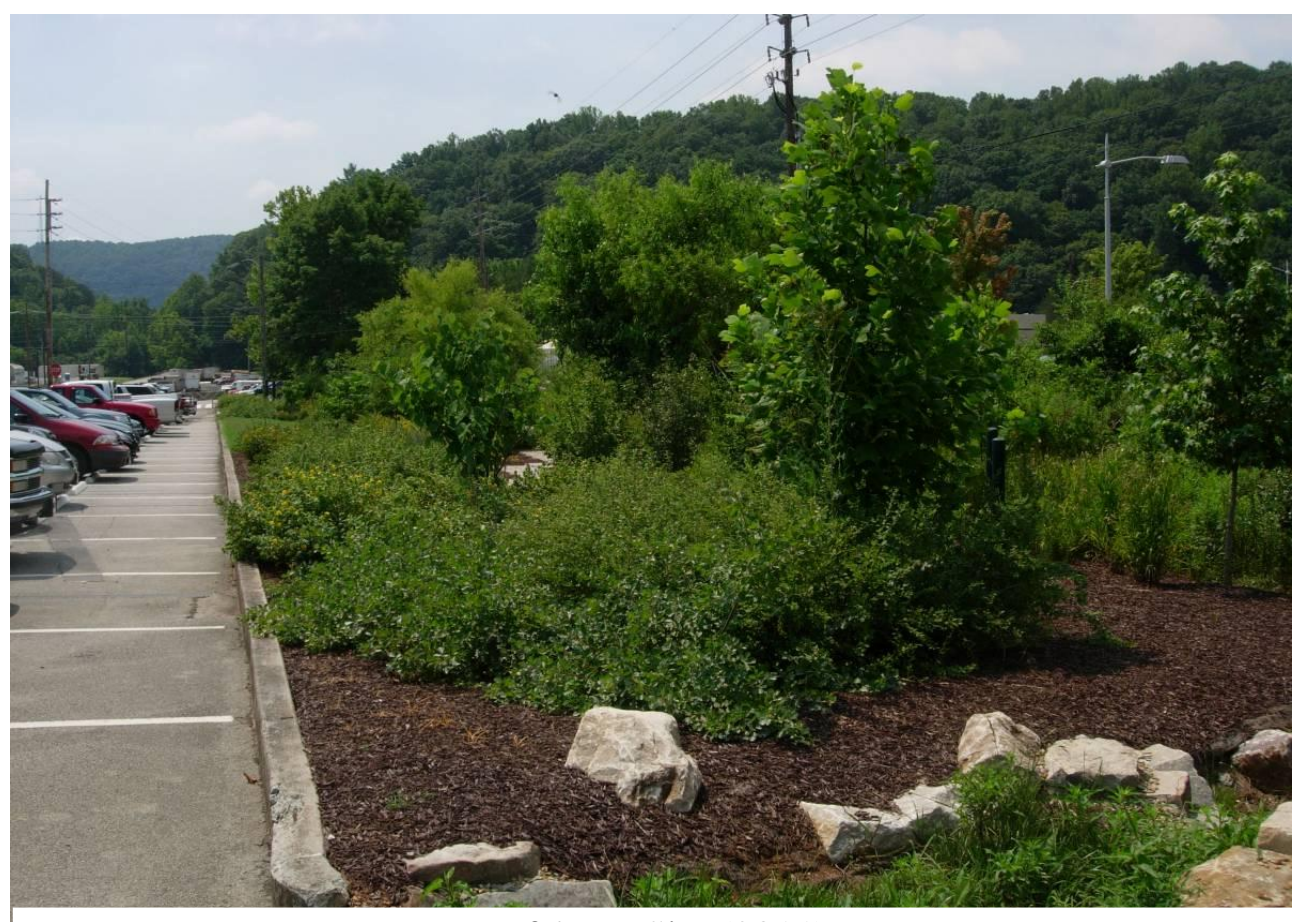

Left/East Site (2011)

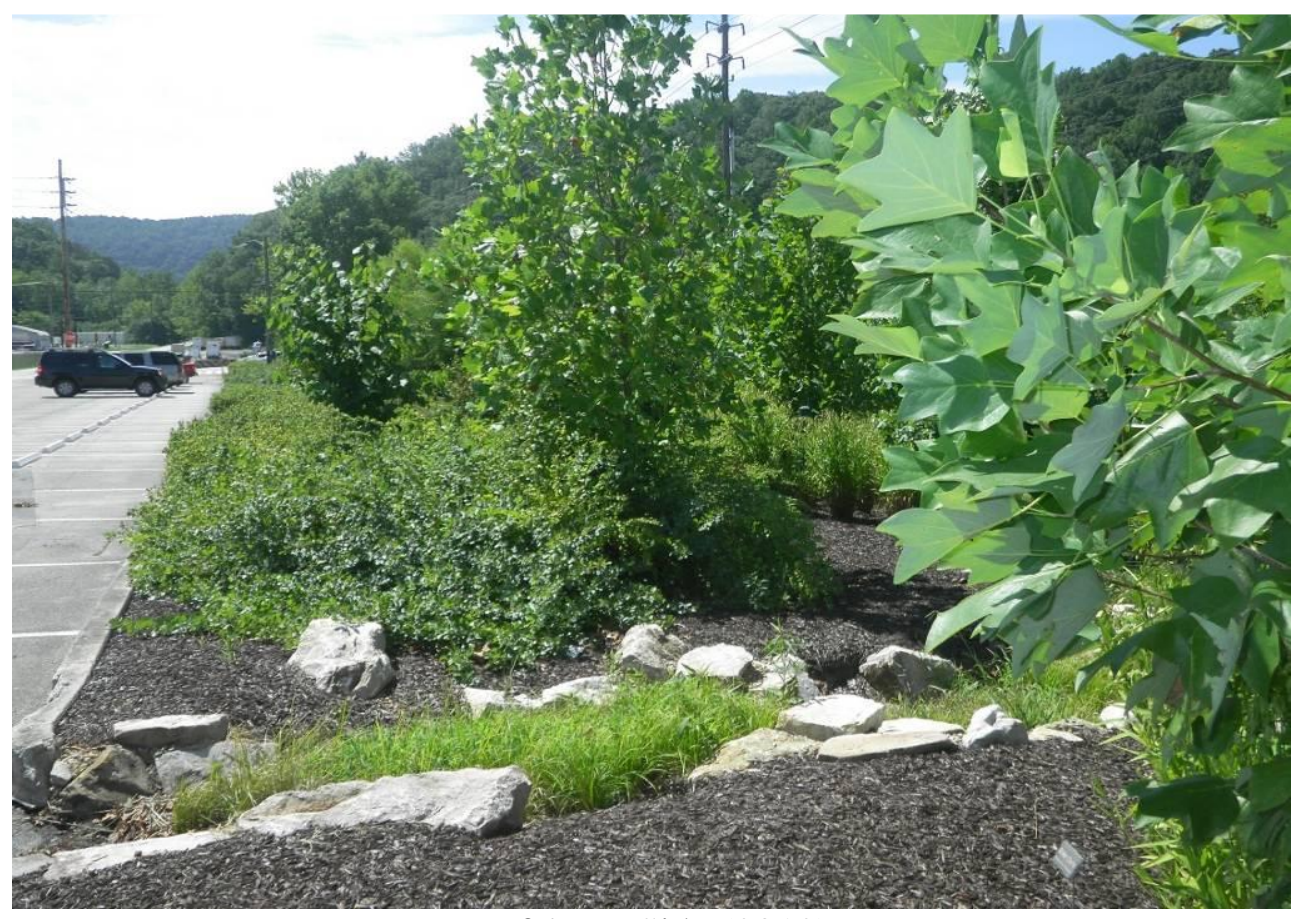

Left/East Side (2012) 


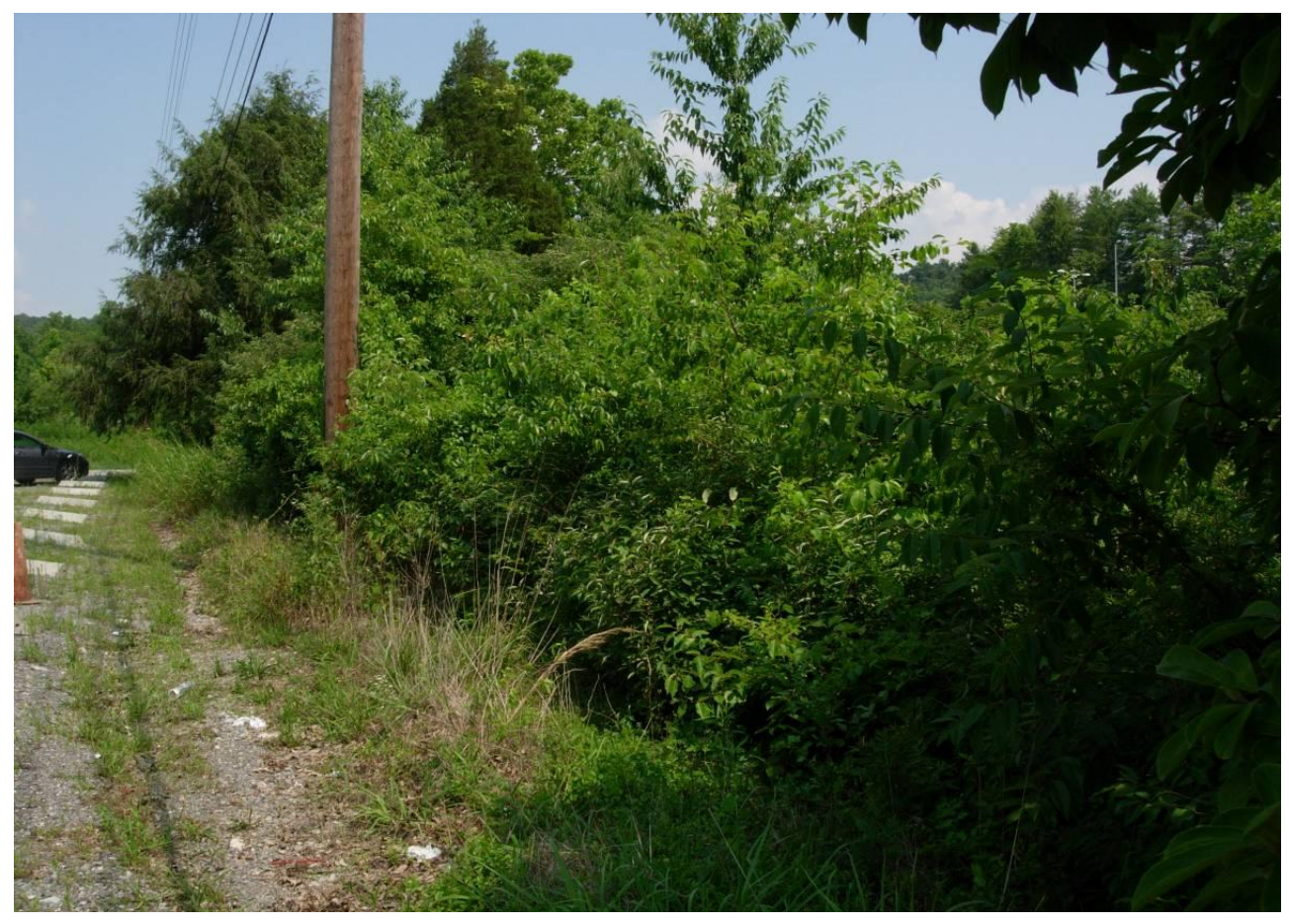

Right/West Site (2011)

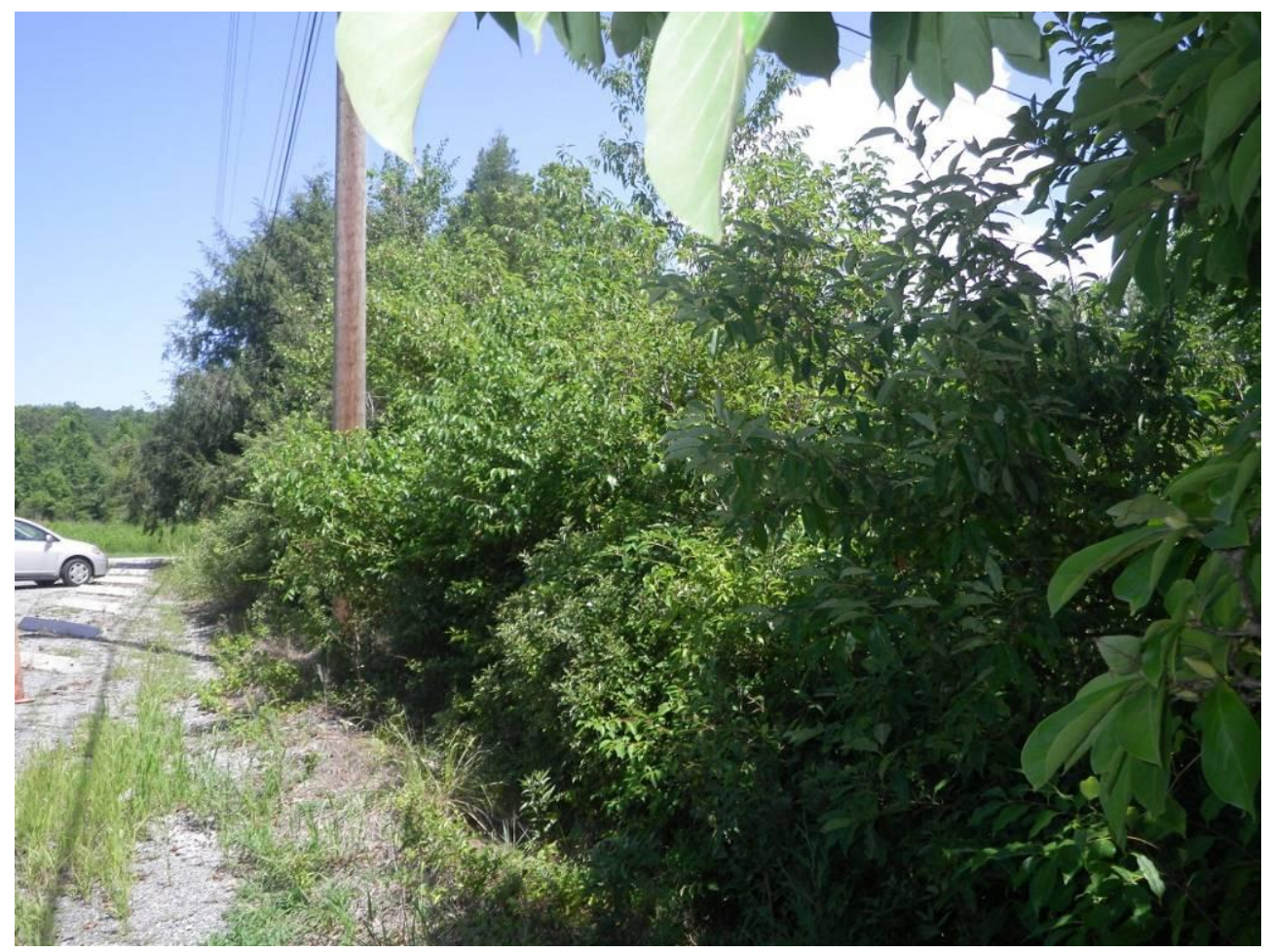

Right/West Side (2012) 
Figure 3. Select Habitat Attributes of the First Creek Reach in 2012.

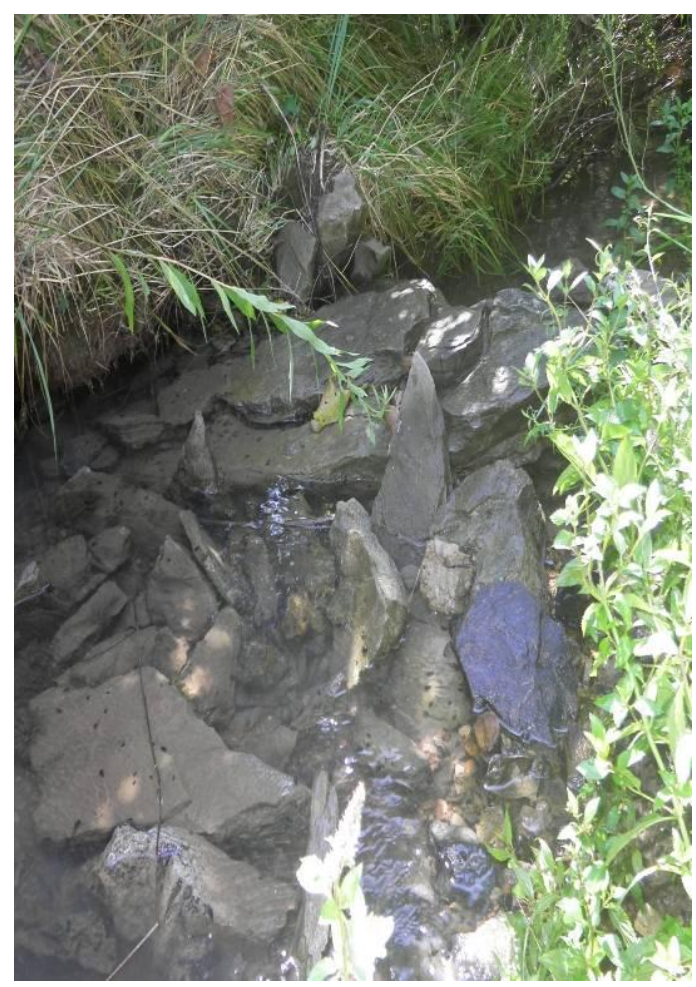

Epifaunal Substrate (favorable)

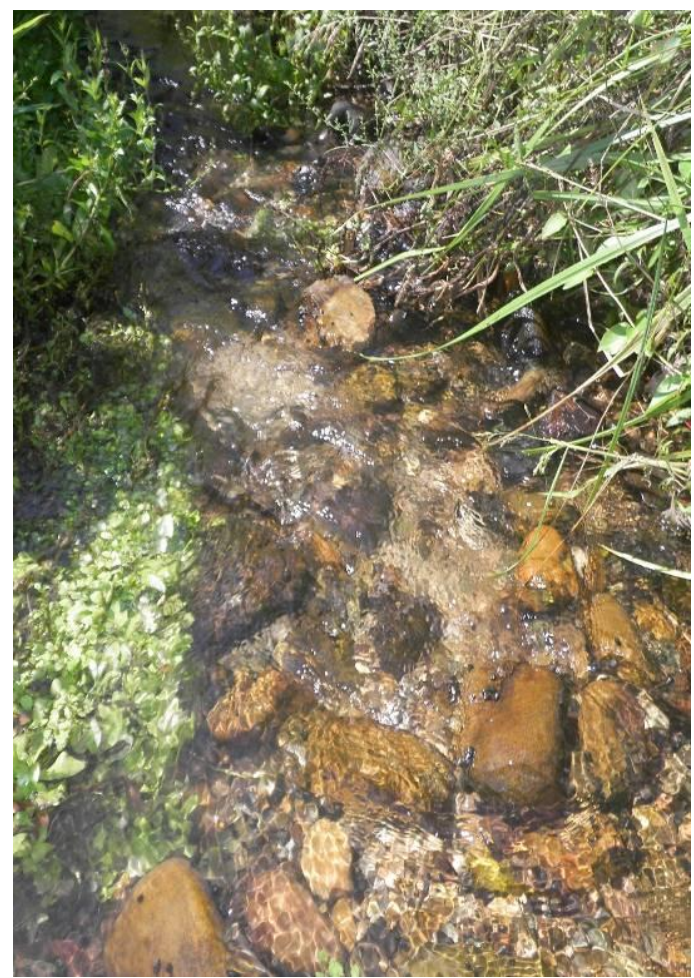

Frequency of Riffles (very frequent)

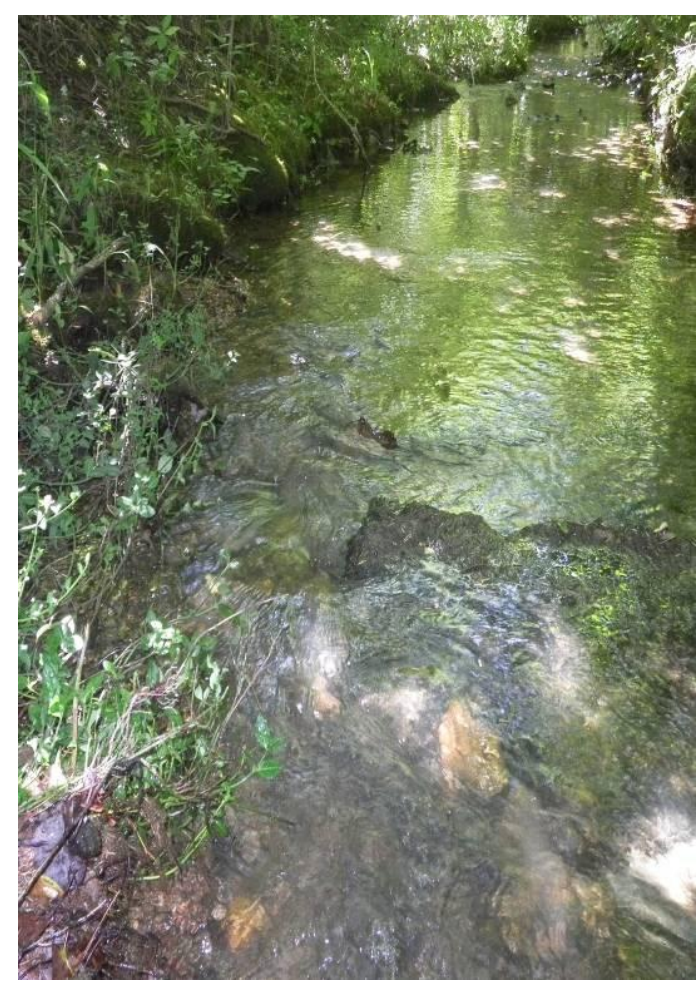

Velocity/Depth Regime (fast-deep)

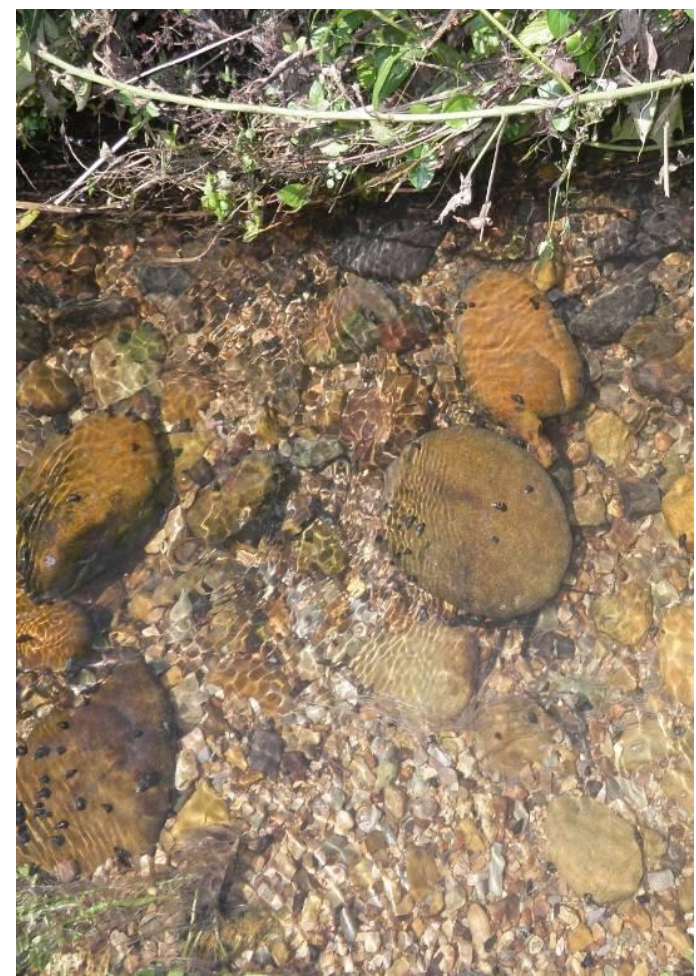

Embeddedness (low sediment) 


\subsubsection{White Oak Creek Habitat Assessment}

White Oak Creek habitat attributes for 2012 were virtually the same as those recorded in 2011, with the exception of noticeable improvements in the riparian vegetative zone width and quality. The 2012 assessment is as follows:

1. Epifaunal Substrate/Available Cover - This reach of White Oak Creek scored in the midsuboptimal range for epifaunal substrate/available cover. It is estimated that approximately $55 \%$ of the substrate is favorable for epifaunal colonization and fish cover. This particular reach provides numerous riffles, some undercut banks, cobble, larger rocks (numerous), and overhanging branches. The area is lacking in presence of logs and snags.

2. Embeddedness - This reach scored in the mid-optimal range for embeddedness. This means that gravel, cobble and boulder particles are $0-25 \%$ surrounded by fine sediment. Gravel, cobble and boulder particles were approximately $15 \%$ surrounded by fine sediment for most of the length of the White Oak Creek reach.

3. Velocity/Depth Regime - The White Oak Creek reach scored in the high suboptimal range for velocity/depth regime. This means that 3 of the 4 velocity/depth regimes (slow deep, slowshallow and fast-shallow) were present. The fast-deep velocity/depth regime was missing in this reach.

4. Sediment Deposition - The White Oak Creek reach scored in the lower optimal range for sediment deposition. This means that there is little or no enlargement of islands or point bars and less than $5 \%$ of the bottom is affected by sediment deposition. The reach contained sediment in certain areas, but it was very minimal.

5. Channel Flow Status - The White Oak Creek reach scored in the mid-optimal range for channel flow. This means that the water reaches the base of both lower banks, and a minimal amount of channel substrate is exposed. Good bank to bank flow was noted in most all locations along the White Oak Creek reach, with no noticeable locations where this wasn't the case.

6. Channel Alteration - The White Oak Creek reach scored in the high suboptimal range for channel alteration. This means that there is some channelization present. The White Oak Creek reach showed some channelization at bridge abutments where rip-rap was applied. Modification of banks probably occurred with development in the area (e.g., buildings, landscaping, roads).

7. Frequency of Riffles (or bends) - The White Oak Creek reach scored in the lower optimal range for frequency of riffles. This means that the frequency of riffles is relatively frequent. Riffles were frequent along this reach, with a ratio of distance between riffles divided by stream width measured at approximately 6:1.

8. Bank Stability (conditions of banks) - The White Oak Creek reach scored in the lower optimal range for bank stability, for both banks. This means that banks are stable where evidence of erosion or bank failure is absent or minimal, with little potential for future problems. This reach showed little to no evidence of erosion or bank failure. 
9. Vegetative Protection (banks) - The White Oak Creek reach scored in the mid-suboptimal range for vegetative protection along both banks. The suboptimal characterization means that approximately $80 \%$ of the stream bank surfaces are covered by vegetation. The White Oak Creek reach showed vegetation coverage along its banks. Habitat quality had been compromised by the invasion of winter creeper, crown-vetch (Coronilla varia) and other invasive plants [e.g. Japanese honeysuckle (Lonicera japonica) and Johnson grass] prior to mitigation in 2011. The 2012 survey revealed significantly fewer invasive plants, largely attributed to the mitigation efforts undertaken in August 2011. There continues to be good tree and shrub growth, with green ash (Fraxinus pennsylvanica) and black willow present in several areas.

10. Riparian Vegetative Zone Width - The White Oak Creek reach scored in the mid marginal range for riparian vegetative zone width. A marginal rating is given when width of the riparian zone is 6-12 meters with evidence of human disturbance. Riparian zone widths were measured from creek banks to mowed areas. The left bank riparian zone averaged 9.3 meters in width and the right bank riparian zone averaged 10.3 meters in width along this reach, excluding managed turf zones. The zone width had drastically increased from what existed in 2011, where the left zone was $2.8 \mathrm{~m}$ and the right was $3.5 \mathrm{~m}$. Riparian zones along this reach are no longer interrupted by extensive mowed areas, and the prevalence of invasive plants was significantly diminished with the mitigation planting efforts of August 2011. The left bank riparian zone is bordered by the High Temperature Materials Laboratory (Building 4515), while the right bank riparian zone is bordered by mowed turf grasses and Southside Avenue. Total potential riparian zone width is restricted by the presence of the building on the left side and by the road on the right side. Riparian zones are also interrupted by bridges (middle, east and west ends). Rip-rap zones at each bridge also interrupt riparian zones along the reach. The best quality riparian areas along this reach existed at creek-side where green ash and black willow shrubs and trees were present. Figure 4 shows both left and right side riparian zones, with comparisons between 2011 (pre-mitigation) and 2012.

Table 3 shows individual ratings for each of the 10 main categories and the overall habitat assessment score for this White Oak Creek reach. The rating given to this site places it well within the category of non-impaired for the 2012 evaluation, as it was rated in 2011. However, the overall score in 2012 (154) was higher than in 2011 (147). Figure 5 provides photographs of select habitat attributes at this reach for 2012. 
Figure 4. White Oak Creek Riparian Zones (2011 [pre-mitigation] and 2012).

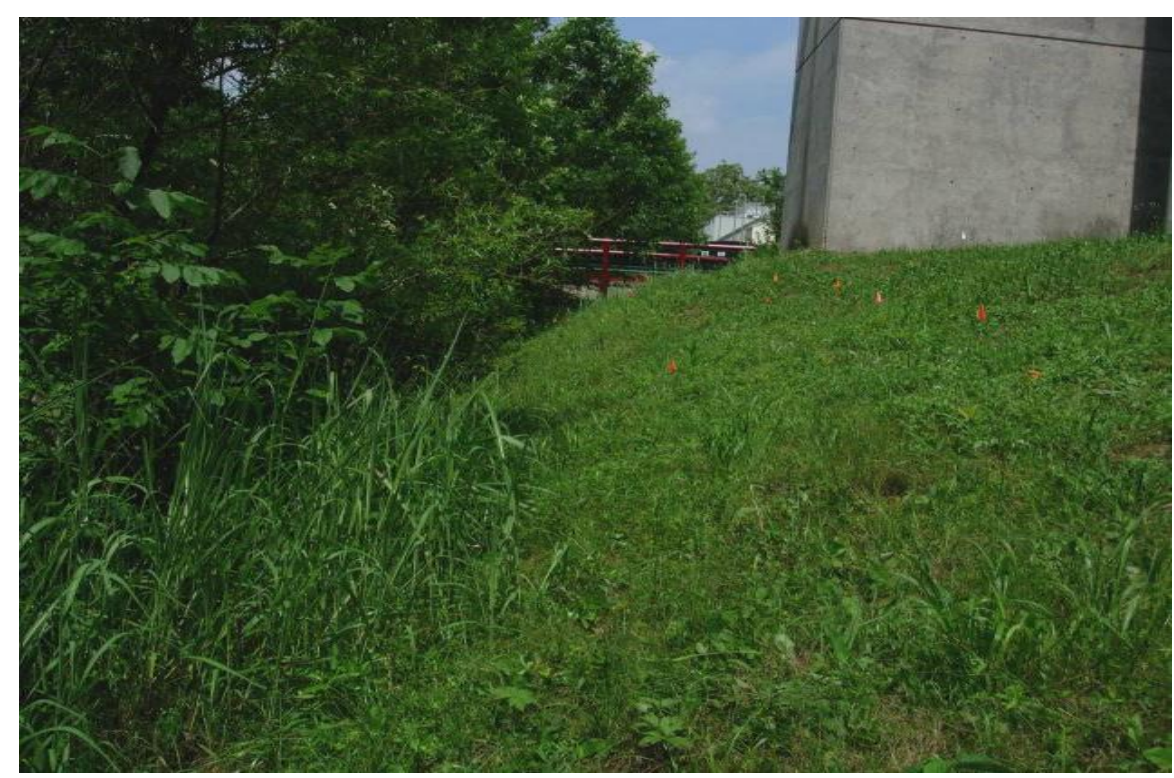

Left/South Side (pre-mitigation - 2011)

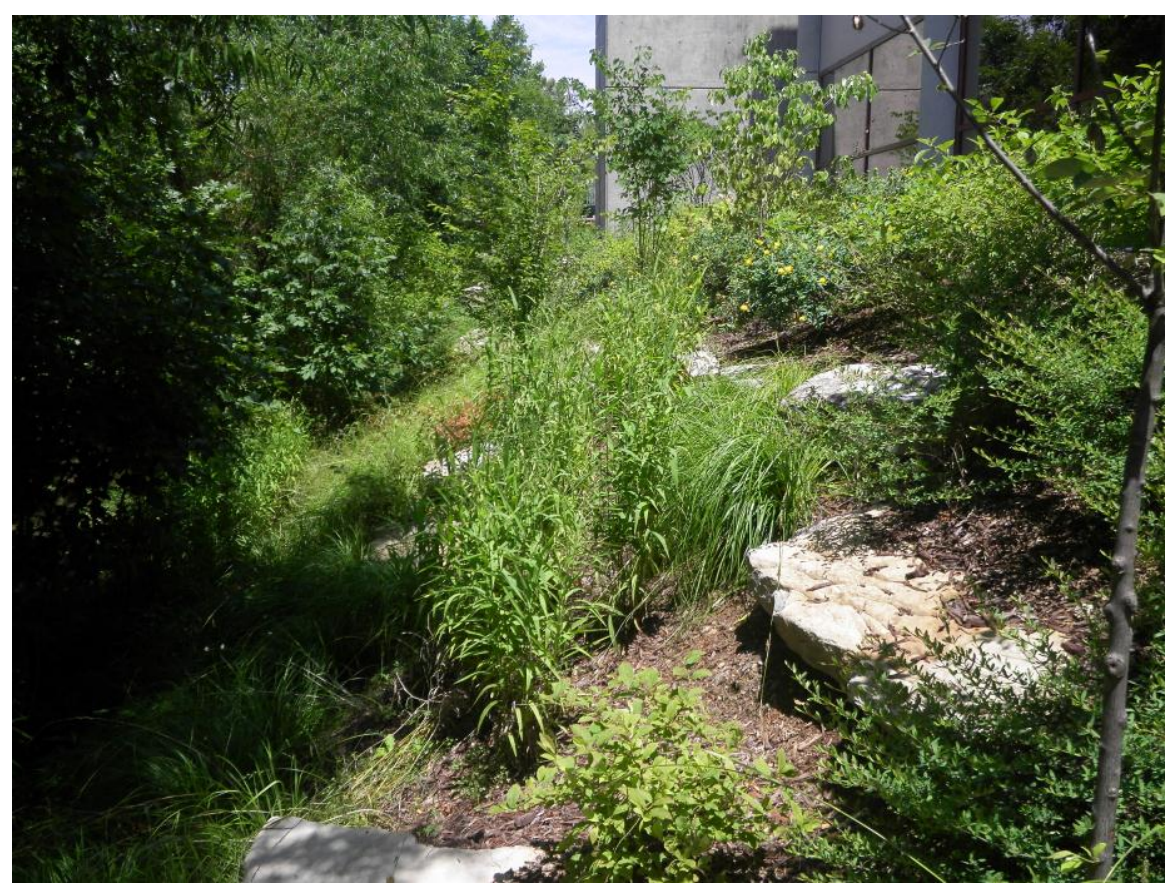

Left/South Side (post-mitigation - 2012) 


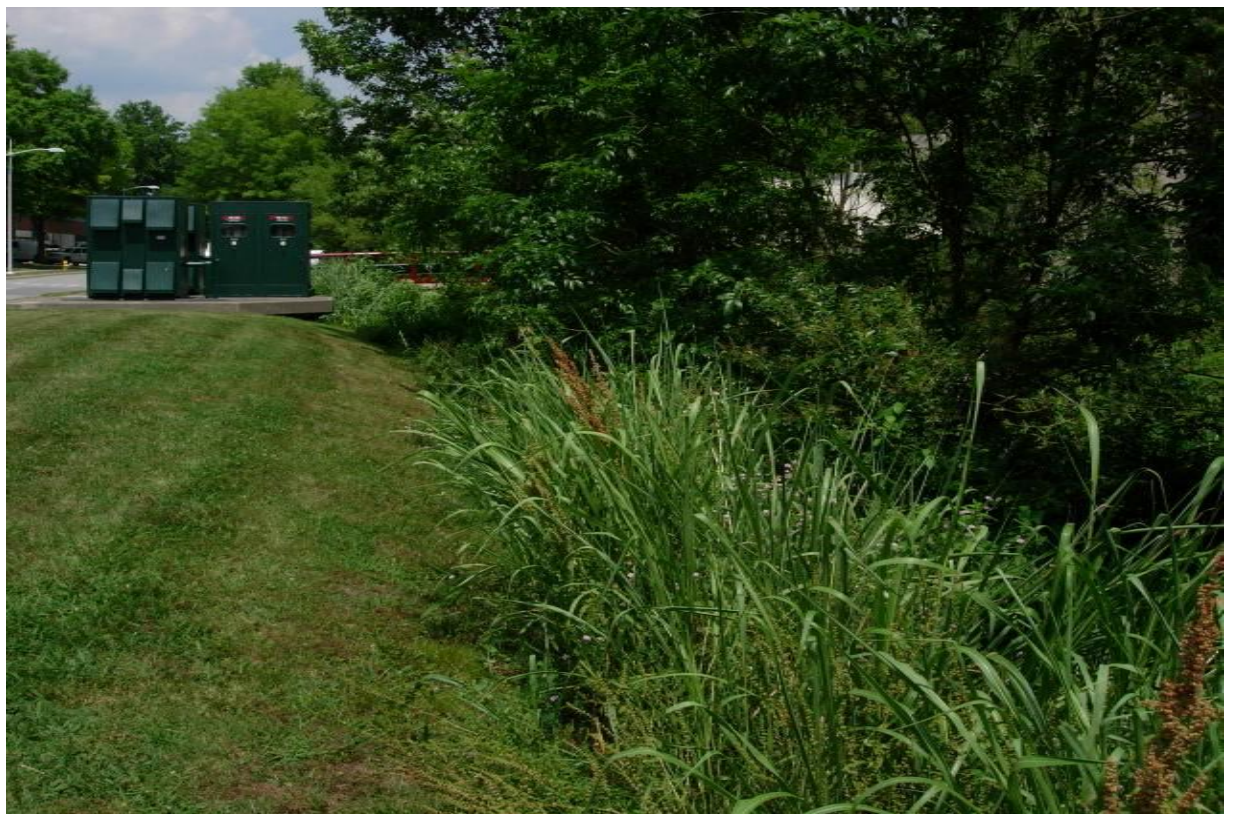

Right/North Side ( pre-mitigation - 2011)

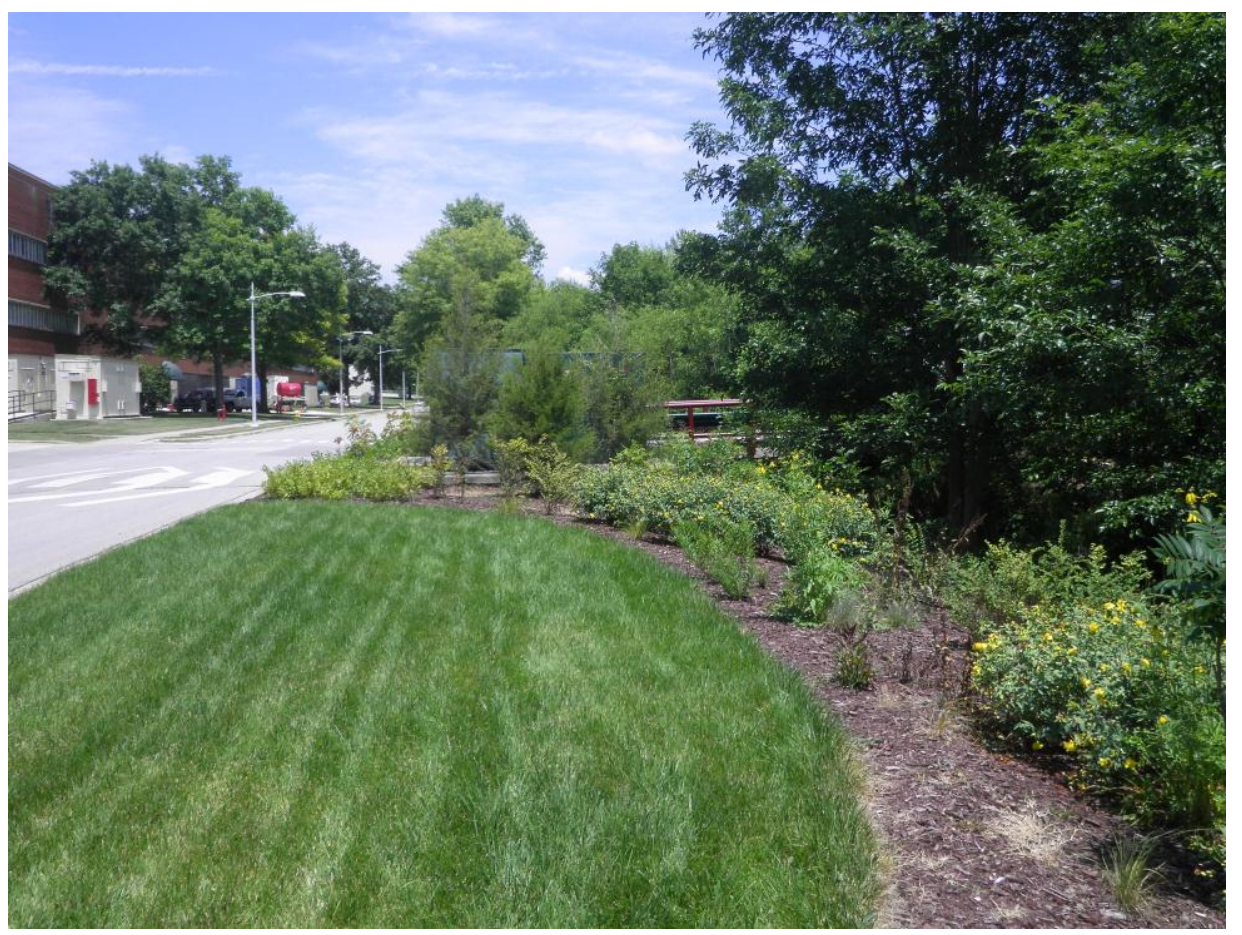

Right/North Side (post-mitigation - 2012) 
Table 3. Habitat Assessment for White Oak Creek Reach.

\begin{tabular}{|l|c|}
\hline PARAMETERS & $\mathbf{0 6 / 1 3 / 2 0 1 2}$ \\
\hline Epifaunal Substrate/Available Cover & 13 \\
\hline Embeddedness & 18 \\
\hline Velocity/depth regime & 15 \\
\hline Sediment deposition & 17 \\
\hline Channel flow status & 18 \\
\hline Channel alteration & 15 \\
\hline Frequency of Riffles & 17 \\
\hline Bank Stability - Left & 9 \\
\hline Bank Stability - Right & 9 \\
\hline Vegetative Protection - Left & 7 \\
\hline Vegetative Protection - Right & 7 \\
\hline Riparian Vegetative Zone Width - Left & 5 \\
\hline Riparian Vegetative Zone Width - Right & 4 \\
\hline \multicolumn{1}{|c|}{ Score (Goal $\geq \mathbf{1 3 1}$ Narrative Rating } & $\mathbf{1 5 4}$ \\
\hline \multicolumn{1}{|c|}{ Non-Impaired } \\
\hline
\end{tabular}


Figure 5. Select Habitat Attributes of the White Oak Creek Reach in 2012.

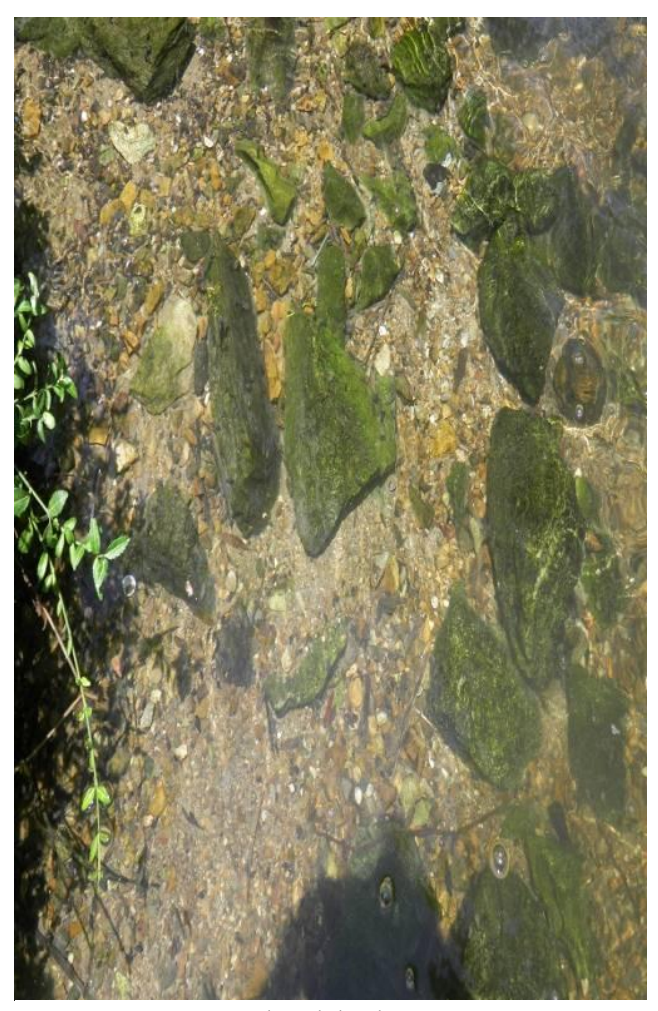

Embeddedness

(rocks free from sediment)

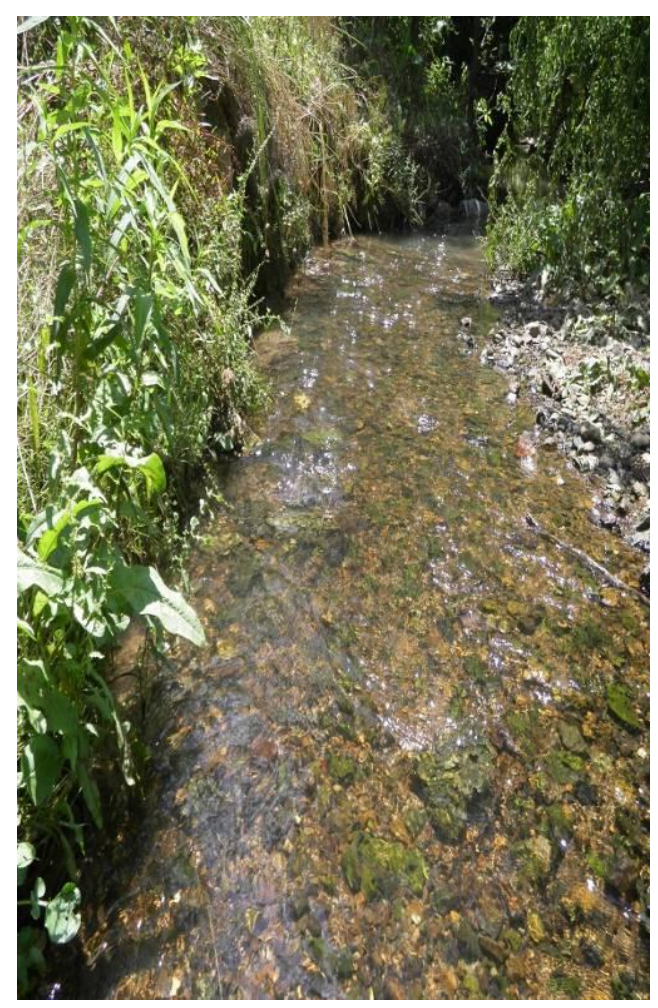

Frequency of Riffles

(relatively frequent)

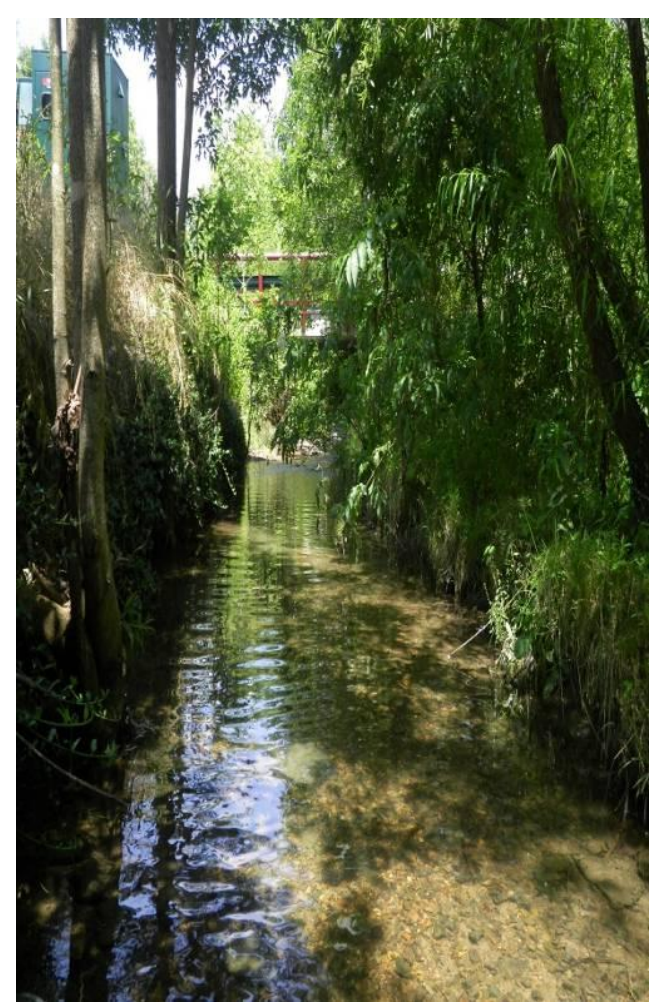

Channel Flow Status

(bank to bank flow)

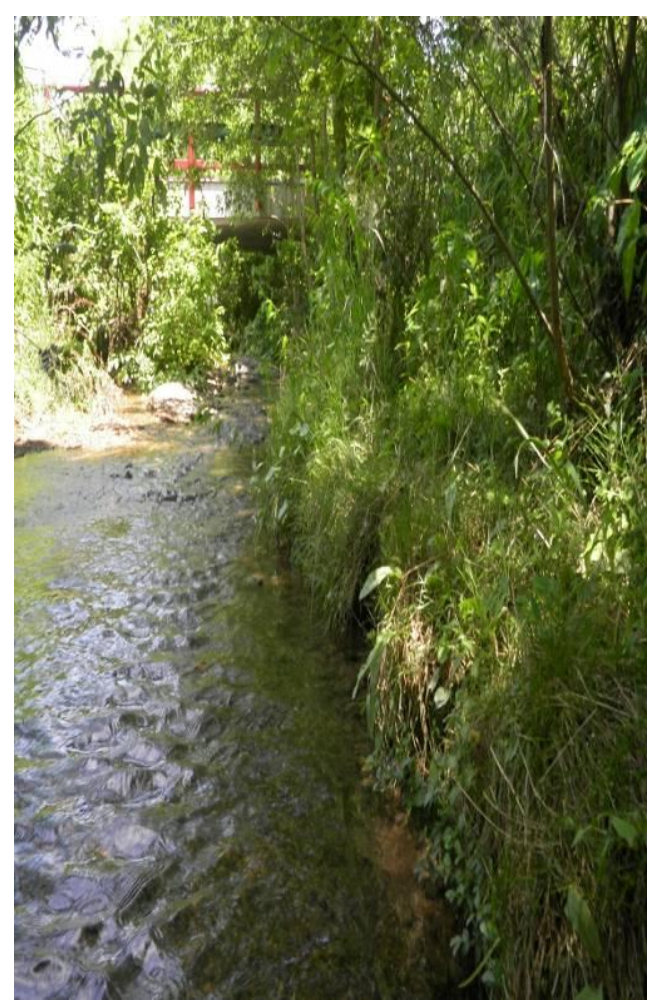

Bank Stability (stable condition) 
The total habitat score for the First Creek reach (161) compares favorably with habitat assessments conducted in other areas of the White Oak Creek watershed. The total score for the White Oak Creek reach (154) is lower than certain habitat assessments conducted in other areas of the White Oak Creek watershed, but is still in the middle range of scores found (Table 4).

Table 4. Habitat Assessment Results for BMAP Sampling Sites in White Oak Creek Watershed, 2012.

\begin{tabular}{|c|c|c|c|c|c|c|}
\hline \multirow[b]{2}{*}{ Habitat parameter } & \multicolumn{6}{|c|}{ Sampling site/habitat score } \\
\hline & FCK 0.1 & FFK 0.2 & MEK 0.6 & $\begin{array}{c}\text { WCK } \\
2.3 \\
\end{array}$ & $\begin{array}{c}\text { WCK } \\
3.9 \\
\end{array}$ & WCK 6.8 \\
\hline $\begin{array}{l}\text { 1. Epifaunal } \\
\text { substrate/available cover }\end{array}$ & 13 & 13 & 18 & 15 & 11 & 20 \\
\hline 2. Embeddedness & 11 & 9 & 13 & 15 & 10 & 18 \\
\hline 3. Velocity/depth regime & 17 & 20 & 18 & 20 & 20 & 20 \\
\hline 4. Sediment deposition & 11 & 17 & 16 & 10 & 17 & 16 \\
\hline 5. Channel flow & 18 & 20 & 19 & 20 & 19 & 20 \\
\hline 6. Channel alteration & 15 & 15 & 18 & 20 & 15 & 20 \\
\hline 7. Frequency of riffles & 11 & 17 & 10 & 15 & 11 & 20 \\
\hline $\begin{array}{l}\text { 8. Bank stability } \\
\text { Left } \\
\text { Right }\end{array}$ & $\begin{array}{l}5 \\
5\end{array}$ & $\begin{array}{l}8 \\
8\end{array}$ & $\begin{array}{l}9 \\
7\end{array}$ & $\begin{array}{l}7 \\
7\end{array}$ & $\begin{array}{l}5 \\
2\end{array}$ & $\begin{array}{l}7 \\
6\end{array}$ \\
\hline $\begin{array}{l}\text { 9. Vegetative protection } \\
\text { Left } \\
\text { Right }\end{array}$ & $\begin{array}{l}7 \\
7\end{array}$ & $\begin{array}{l}6 \\
6\end{array}$ & $\begin{array}{l}9 \\
6\end{array}$ & $\begin{array}{l}8 \\
8\end{array}$ & $\begin{array}{l}9 \\
7\end{array}$ & $\begin{array}{l}5 \\
6\end{array}$ \\
\hline $\begin{array}{l}\text { 10. Riparian vegetative } \\
\text { zone width } \\
\text { Left } \\
\text { Right }\end{array}$ & $\begin{array}{l}5 \\
3\end{array}$ & $\begin{array}{l}3 \\
2\end{array}$ & $\begin{array}{c}10 \\
7\end{array}$ & $\begin{array}{l}10 \\
10\end{array}$ & $\begin{array}{l}4 \\
1\end{array}$ & $\begin{array}{c}1 \\
10\end{array}$ \\
\hline Total score & 128 & 144 & 150 & 165 & 131 & 169 \\
\hline $\begin{array}{l}\text { Ecoregion 67f habitat goal } \\
(\geq 131)\end{array}$ & Fail & Pass & Pass & Pass & Fail & Pass \\
\hline
\end{tabular}




\subsection{Riparian Zone Vegetation Survey Results}

\subsubsection{First Creek}

Initial vegetation evaluations were conducted at the First Creek site in 2008 to gain a baseline for planned mitigation on the site. The existing riparian vegetation at that time was a mix of native trees and shrubs, with a strong component of invasive species such as Chinese privet (Ligustrum sinensis), thorny olive (Elaeagnus pungens), tree-of-heaven (Ailanthus altissima), Bradford pear (Pyrus calleryana), Japanese honeysuckle, and typical landscape species including crab apple (Malus sp.) and fescue (Festuca sp.). The northern 50 meters of riparian zone was planted with a mix of riparian trees and shrubs (Table 5), as part of the stream remediation in 1996. A large percentage of the original planted vegetation remained and had been supplemented by extensive expansion, creating a dense thicket of smaller trees and shrubs in certain areas. Existing trees and shrubs extended no more than $8 \mathrm{~m}$ on each side of the stream and the remainder of the buffer was a fescue-based turf grass.

Table 5. Trees and Shrubs Planted in Study Section of First Creek as Part of a Wetland Remediation in 1996.

\begin{tabular}{|l|c|c|c|}
\hline Species & $\begin{array}{c}\text { Number } \\
\text { Planted }\end{array}$ & $\begin{array}{c}\text { Still } \\
\text { Present }\end{array}$ & $\begin{array}{c}\text { Percent } \\
\text { remaining }\end{array}$ \\
\hline Silky dogwood & 20 & 18 & 90 \\
\hline Gray dogwood & 17 & 13 & 76 \\
\hline Spicebush & 14 & 12 & 86 \\
\hline Winterberry holly & 14 & 10 & 71 \\
\hline Buttonbush & 7 & 5 & 71 \\
\hline Hazelnut & 4 & 4 & 100 \\
\hline Flowering dogwood & 6 & 4 & 66 \\
\hline American holly & 4 & 1 & 25 \\
\hline Sugar maple & 3 & 3 & 100 \\
\hline Black walnut & 1 & 1 & 100 \\
\hline Mockernut hickory Total & 1 & 1 & 100 \\
\hline & 91 & 72 & 79 \\
\hline
\end{tabular}

In 2008 plans were established for the mitigation of the eastern First Creek riparian buffer. An environmental landscape plan was developed that included native trees, shrubs and herbaceous species (Appendix B). Planting was completed in September 2009.

A riparian zone vegetation survey was conducted in June, 2012, to document the survivorship/success rate of the planted species. Eleven 10x5 meter plots were established on the east side of the creek where mitigation measures were taken. Plot locations were those established during the June 2011 survey. This included both plots directly adjacent to the creek and plots further upslope in the riparian zone. A total of 58 plant species were recorded on the site in 2012 (Appendix C - Table C1), an increase from the 51 plant species recorded in 2011. Of these 58 species, 14 species were originally part of the mitigation planting plan. 
Overall, there was good survivorship of planted species. However, there were some areas that contained dead plant growth. Dead plant growth within survey plots included a few silky dogwoods (Cornus amomum), one spicebush (Lindera benzoin), and one gro-low sumac (Rhus aromatica). A brief survey was conducted along the entire eastern edge of First Creek to record any dead plants, the results of which are listed in Table 6. Although there is still good vegetation coverage in the riparian zone, there are plans to replace some of the dead plants to further improve coverage.

Table 6. Dead and Dying Plants Recorded in Riparian Zone Along First Creek Reach in July, 2012.

\begin{tabular}{|c|c|}
\hline Species & Number of Individuals \\
\hline Black-eyed Susan & 18 \\
\hline Golden St. John's wort & 1 \\
\hline Gro-low sumac & 14 \\
\hline Little bluestem & 4 \\
\hline Prairie coneflower & 4 \\
\hline Prairie dropseed & 4 \\
\hline Purple coneflower & 5 \\
\hline River oats & 6 \\
\hline Scaly blazing star & 1 \\
\hline Total & 57 \\
\hline
\end{tabular}

Planted groundcover species thriving ( $>25 \%$ cover) on the site included gro-low sumac, and river oats (Chasmanthium latifolium). There were also areas where invasive winter creeper was prevalent. Dense growths of previously planted silky dogwood continued to flourish at the site (almost 152 stems counted in 11 plots), along with winterberry (Ilex verticillata). Black willow trees and shrubs were also prevalent along the creek in certain areas.

Groundcover at this site averaged approximately $45 \%$ across all plots. The relatively low percent groundcover is attributable to several things. Groundcover is shaded out by thick shrub growth in certain areas adjacent to the creek. In addition, there are relatively large areas of wood chips that were incorporated into the planting plan in some areas of the upper riparian zone. Rock incorporated into the rain gardens along the reach also accounted for lower vegetative groundcover in certain survey plots.

Canopy cover at the site averaged over $56 \%$ across all plots. However, this varied based on location of the survey plot. Canopy cover generally averaged about $76 \%$ adjacent to the creek where thick growths of trees and shrubs were common ( $\mathrm{N}=6$ plots). Areas further upslope from the stream banks generally averaged less than $22 \%$ canopy cover, where newly planted areas were dominated by smaller saplings and shrubs, and herbaceous species ( $N=5$ plots).

Invasive plants were not found to be a major concern at the overall site, averaging less than $9 \%$ of the cover across the eleven plots. Invasive species recorded on the site included winter creeper, Nepal grass (Microstegium vimineum), crown vetch (Securigera varia), and Japanese honeysuckle. Winter creeper was by far the most common invasive species recorded at the site, 
accounting for almost $57 \%$ (by cover) of invasive species records. This species could become a concern in the future. Ten thorny olive shrubs were also recorded on the site, an increase from the one shrub found in 2011.

Figure 6 provides a photographic comparison of site condition changes between 2008 and 2012 . 
Figure 6. First Creek Reach in 2011 and 2012.

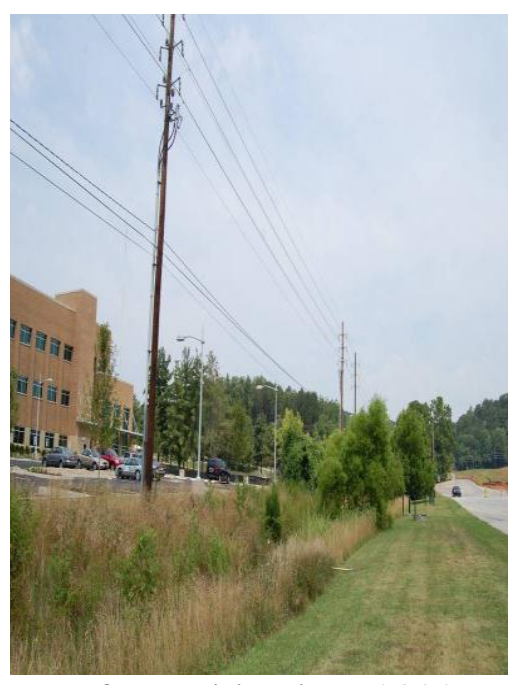

Before Mitigation (2008)

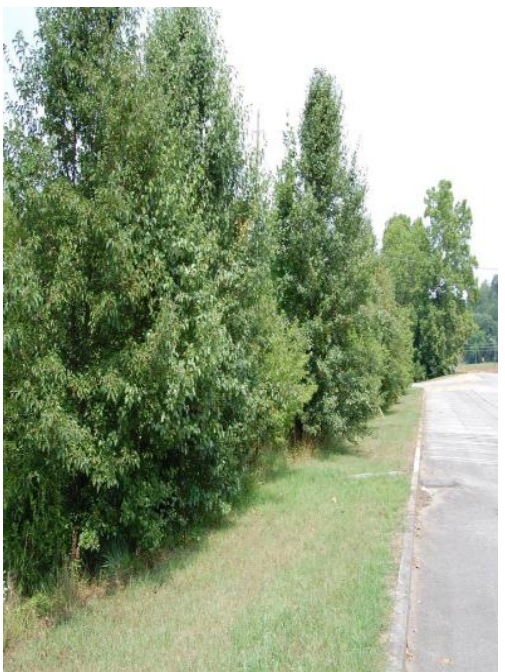

Before Mitigation (2008)

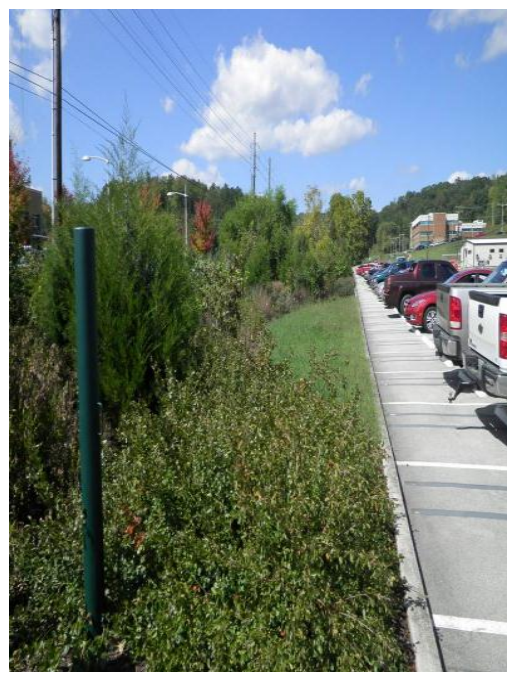

After Mitigation (2011)

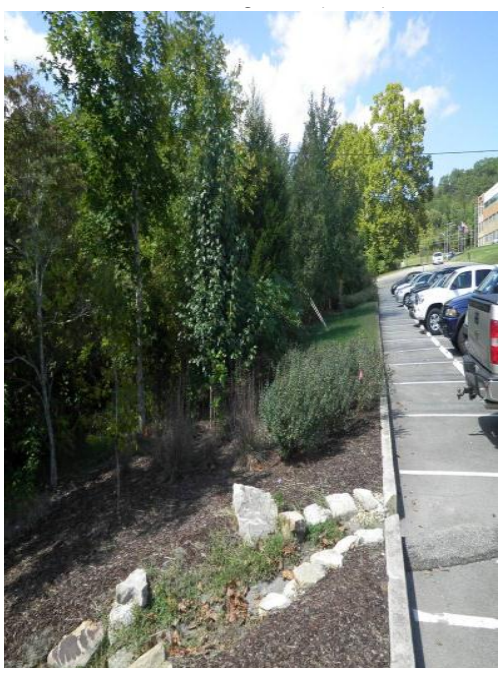

After Mitigation (2011)

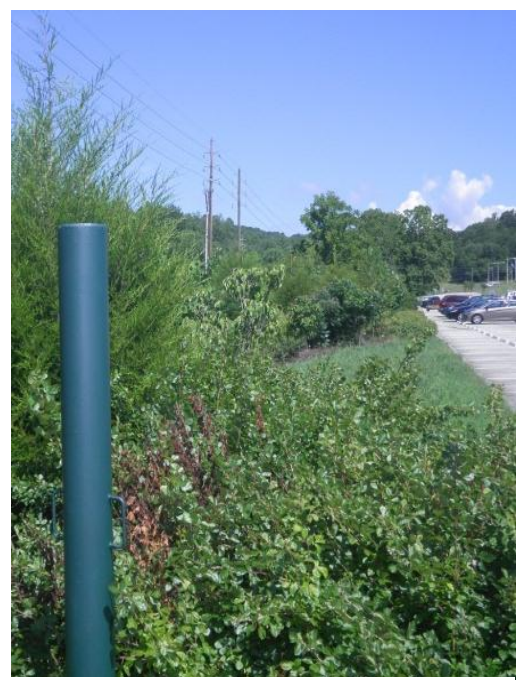

Current Appearance (2012)

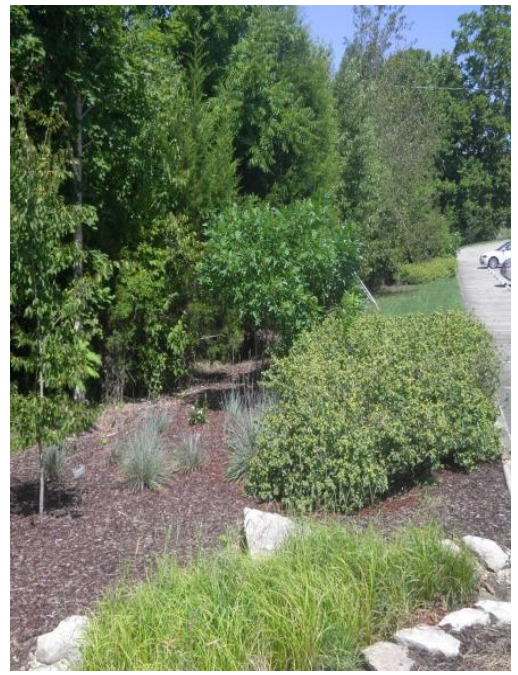

Current Appearance (2012) 


\subsubsection{White Oak Creek}

Mitigation planting was completed at this site in August 2011. A riparian zone vegetation survey was conducted in June, 2012. Thirteen 10x5 meter plots were established on alternating sides of the creek from a baseline plant assessment conducted in May-June, 2011, prior to mitigation. The survey range included both plots directly adjacent to the creek and plots further upslope, including areas adjacent to the road to the north and the building to the south of the creek. A total of 65 plant species were recorded on the site in 2012 (Appendix C - Table C2), a significant increase from the 34 species recorded on site before mitigation efforts in 2011. Green ash and black willow trees were prevalent in the lower riparian zone near the creek. Also prevalent in the lower riparian zone were green ash, eastern redbud (Cercis canadensis), black willow, and silky dogwood shrubs.

Groundcover at this site averaged almost $52 \%$ across all plots ( $\mathrm{N}=13$ plots). Percent groundcover was somewhat higher in plots adjacent to the creek ( $60.1 \%, \mathrm{~N}=7$ plots), then in plots in the upper riparian zone $(42.5 \%, \mathrm{~N}=6)$. Invasive plants were mostly found in the groundcover in the lower portion of the riparian zone adjacent to the creek, including winter creeper, Johnson grass and Nepal grass. However, invasive species accounted for an average of only $5 \%$ of the groundcover in this area ( $\mathrm{N}=7$ plots), a significant reduction from the $36 \%$ they made up along the creek prior to mitigation efforts. This decrease is likely due to mitigation planting efforts that involved removal of invasives and replacement with native plants. About $14 \%$ of the cover in the upper slope still consists of mowed turf grasses ( $\mathrm{N}=6$ plots), a reduction from the $50 \%$ that was present prior to mitigation. Wood chips constituted a relatively high percentage of the upslope sample plots ( $40 \%, \mathrm{~N}=6$ plots). The wood chips and remaining turf grass areas on the site are those that were incorporated into the overall landscaping/mitigation plan along with the native plantings. Appendix D contains the mitigation planting scheme for the White Oak Creek reach. Only a limited number of dead plantings $(\mathrm{N}=8)$ were noted across the thirteen total survey plots. Although plant cover is very good along the reach, there are still plans to replace dead plantings to assure that good coverage is maintained.

Canopy cover at the site averaged almost 57\% across all plots. However, there was little canopy cover in the upper slope plots $(21 \%, \mathrm{~N}=6$ plots) where low herbaceous growth was dominant. Canopy cover averaged $87 \%$ in the lower riparian zone ( $\mathrm{N}=7$ plots) where shrubs and trees were present. The canopy species in this area were almost exclusively green ash and black willow in 2011, but now include a diverse mix of green ash, black willow, American sycamore (Platanus occidentalis), and other trees.

Figure 7 provides a photographic comparison of site condition changes between 2011 and 2012. 
Figure 7. White Oak Creek Reach in 2011 and 2012.

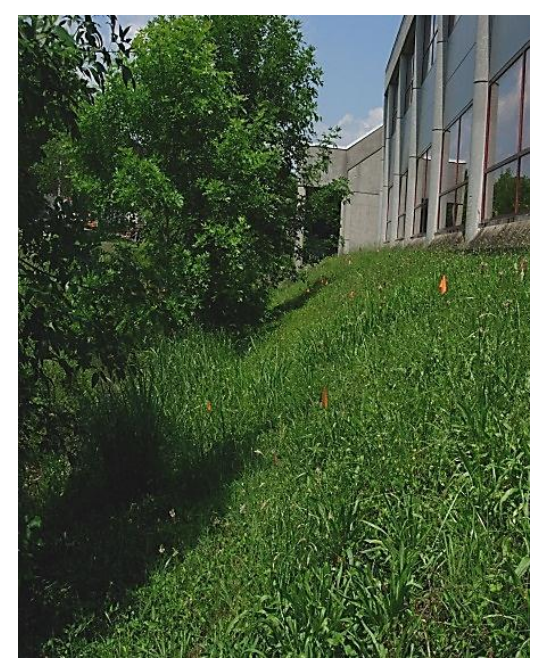

Before Mitigation (2011)

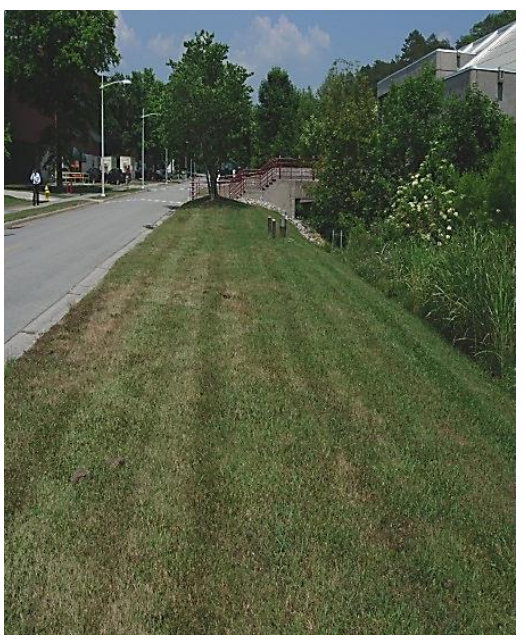

Before Mitigation (2011)

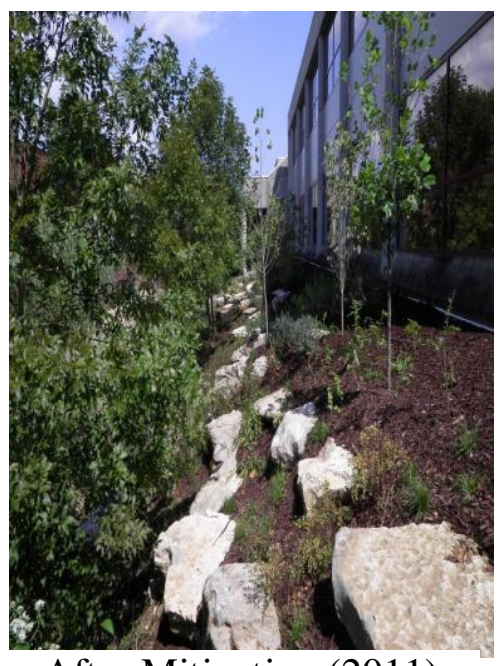

After Mitigation (2011)

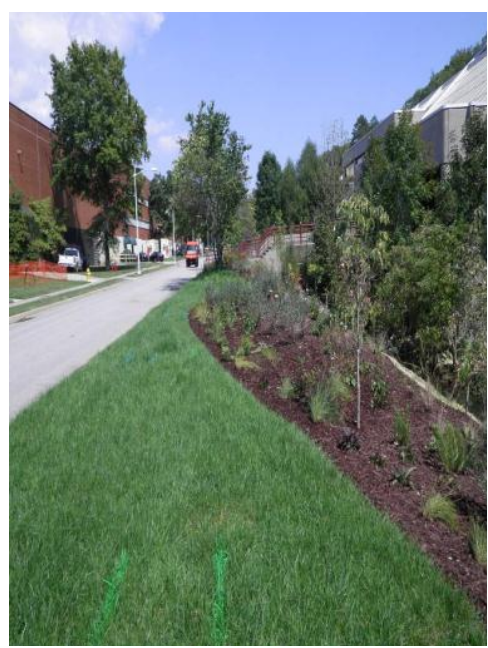

After Mitigation (2011)

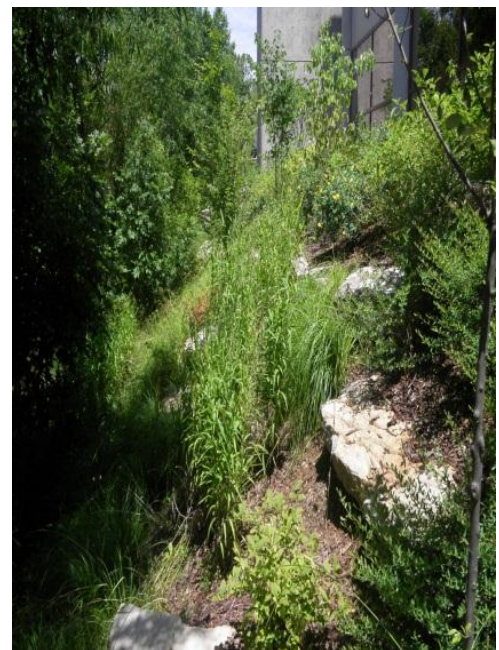

Current Appearance (2012)

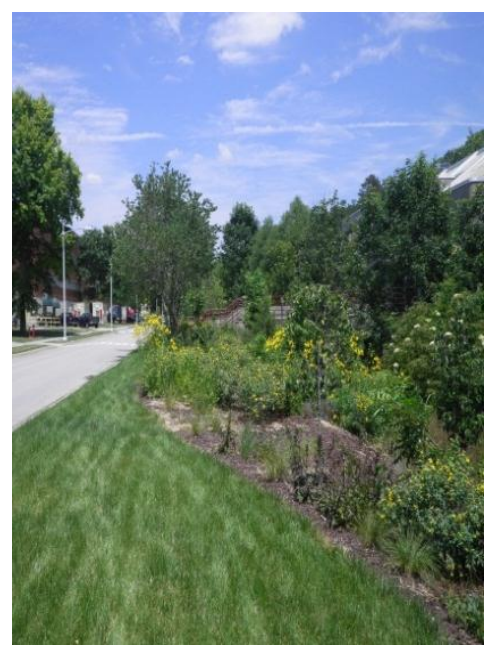

Current Appearance (2012) 


\subsection{Benthic Macroinvertebrate Communities}

\subsubsection{First Creek}

A moderately diverse benthic macroinvertebrate population was recorded in this reach of First Creek in 2012, although somewhat lower than certain reference sites. This included some less tolerant taxa typically found in clear streams. In the U.S. Environmental Protection Agency's protocols for benthic macroinvertebrate sampling, a number of factors can be assessed to determine the health of a waterway. One such factor is the presence of Emphemeroptera/ Plecoptera/ Trichoptera (EPT) taxa. As the number of EPT macroinvertebrate taxa is expected to be lower in areas with greater perturbation occurring, the number of EPT taxa can help gauge the health of a site. A total of seven different families of EPT invertebrates were found in the First Creek Reach site, a slight increase over the six families of EPT invertebrates recorded in 2011. Four different types of more tolerant taxa were also found. Table 7 contains a comparison of 2011 and 2012 results. Habitats sampled included riffles, rocks, root wads and vegetation.

Table 7. Results of Benthic Community Sampling at the First Creek Reach, July 6, 2012.

\begin{tabular}{|c|c|c|c|c|}
\hline & \multicolumn{2}{|c|}{2011 (pre-mitigation) } & \multicolumn{2}{|c|}{2012 (post-mitigation) } \\
\hline Taxa & No. of Taxa & Density $^{1}$ & No. of Taxa & Density $^{1}$ \\
\hline \multicolumn{5}{|c|}{ EPHEMEROPTERA } \\
\hline Baetidae & & & 1 & $\mathrm{R}$ \\
\hline Heptageniidae & 1 & $\mathrm{C}$ & 2 & $\mathrm{R}$ \\
\hline \multicolumn{5}{|l|}{ PLECOPTERA } \\
\hline Leuctridae & 1 & $\mathrm{C}$ & 1 & $\mathrm{R}$ \\
\hline Peltoperlidae & 1 & $\mathrm{R}$ & 1 & $\mathrm{R}$ \\
\hline \multicolumn{5}{|l|}{ TRICHOPTERA } \\
\hline Hydropsychidae & 2 & $\mathrm{R}$ & 2 & $\mathrm{C}$ \\
\hline Leptoceridae & 1 & $\mathrm{R}$ & 1 & $\mathrm{R}$ \\
\hline Limnephilidae & 1 & $\mathrm{C}$ & 1 & $\mathrm{R}$ \\
\hline \multicolumn{5}{|l|}{ DIPTERA } \\
\hline Ceratopogonidae & & & 1 & $\mathrm{R}$ \\
\hline Culicidae & & & 1 & $\mathrm{R}$ \\
\hline Tipulidae & & & 1 & $\mathrm{R}$ \\
\hline \multicolumn{5}{|c|}{ ODONATA (Anisoptera) } \\
\hline Aeshnidae & 1 & $\mathrm{R}$ & & \\
\hline \multicolumn{5}{|c|}{ ODONATA (Zygoptera) } \\
\hline Coenagionidae & 1 & $\mathrm{R}$ & & \\
\hline \multicolumn{5}{|l|}{ COLEOPTERA } \\
\hline Dryopidae & & & 1 & $\mathrm{R}$ \\
\hline Elmidae & 1 & $\mathrm{C}$ & 1 & $\mathrm{C}$ \\
\hline
\end{tabular}




\begin{tabular}{|c|c|c|c|c|}
\hline & \multicolumn{2}{|c|}{2011 (pre-mitigation) } & \multicolumn{2}{|c|}{2012 (post-mitigation) } \\
\hline Taxa & No. of Taxa & Density $^{1}$ & No. of Taxa & Density \\
\hline \multicolumn{5}{|c|}{ COLEOPTERA (cont'd) } \\
\hline Psephenidae & 1 & $\mathrm{C}$ & 1 & $\mathrm{C}$ \\
\hline \multicolumn{5}{|l|}{ HEMIPTERA } \\
\hline Nephidae & 1 & $\mathrm{R}$ & & \\
\hline Gerridae & 1 & $\mathrm{C}$ & 1 & $\mathrm{R}$ \\
\hline Notonectidae & 1 & $\mathrm{R}$ & & \\
\hline Veliidae & 1 & $\mathrm{C}$ & & \\
\hline \multicolumn{5}{|l|}{ TOLERANT TAXA } \\
\hline OLIGOCHAETA & 2 & $\mathrm{C}$ & 1 & $\mathrm{R}$ \\
\hline AMPHIPODA & 1 & $\mathrm{R}$ & 1 & A \\
\hline ISOPODA & 1 & A & & \\
\hline CHIRONOMIDAE & 1 & $\mathrm{R}$ & 1 & $\mathrm{R}$ \\
\hline SIMULIIDAE & 1 & $\mathrm{C}$ & 1 & $\mathrm{R}$ \\
\hline PLANARIIDAE & 1 & $\mathrm{R}$ & & \\
\hline DECAPODA & 1 & $\mathrm{R}$ & 1 & $\mathrm{C}$ \\
\hline \multicolumn{5}{|l|}{ GASTROPODA } \\
\hline Pleuroceridae & 2 & A & 3 & A \\
\hline HYDRACARINA & 1 & $\mathrm{C}$ & 1 & $\mathrm{R}$ \\
\hline
\end{tabular}

When compared to the invertebrate survey taken in 2011, there was a slight decrease in the number of taxa recorded $(2011=26,2012=25)$. The density of taxa seen also decreased, with the majority of taxa falling into the rare category in 2012, whereas the majority of taxa were either common or abundant in 2011. However, such fluctuation is considered normal in annual surveys. The discrepancy in numbers does not necessarily stem from increased perturbation at the site, as a number of more sensitive species were found in the creek. The survey could have been affected by other factors, such as varying weather conditions.

\subsubsection{White Oak Creek}

A moderately diverse benthic macroinvertebrate population was recorded in this reach of White Oak Creek. This included four more tolerant taxa commonly found in ORR streams, as well as six different families of EPT macroinvertebrates. Table 8 contains a comparison of 2011 and 2012 results. Habitats sampled included riffles, wood, rocks and root wads. 
Table 8. Results of Benthic Community Sampling at the White Oak Creek Reach, July 6, 2012.

\begin{tabular}{|c|c|c|c|c|}
\hline & \multicolumn{2}{|c|}{2011 (pre-mitigation) } & \multicolumn{2}{|c|}{2012 (post-mitigation) } \\
\hline Taxa & No. of Taxa & Density $^{1}$ & No. of Taxa & Density $^{1}$ \\
\hline \multicolumn{5}{|c|}{ EPHEMEROPTERA } \\
\hline Baetidae & 2 & $\mathrm{C}$ & 1 & $\mathrm{R}$ \\
\hline Heptageniidae & 1 & $\mathrm{R}$ & 2 & $\mathrm{C}$ \\
\hline \multicolumn{5}{|l|}{ PLECOPTERA } \\
\hline Leuctridae & 1 & $\mathrm{R}$ & & \\
\hline \multicolumn{5}{|l|}{ TRICHOPTERA } \\
\hline Hydropsychidae & 2 & $\mathrm{R}$ & 1 & $\mathrm{C}$ \\
\hline Hydroptilidae & 1 & $\mathrm{C}$ & 1 & $\mathrm{C}$ \\
\hline Limnephilidae & & & 1 & $\mathrm{R}$ \\
\hline Uenoidae & 1 & $\mathrm{C}$ & 1 & $\mathrm{C}$ \\
\hline \multicolumn{5}{|l|}{ DIPTERA } \\
\hline Ceratopogonidae & & & 1 & $\mathrm{R}$ \\
\hline Culicidae & & & 1 & $\mathrm{R}$ \\
\hline \multicolumn{5}{|c|}{ ODONATA (Anisoptera) } \\
\hline Aeshnidae & & & 1 & $\mathrm{R}$ \\
\hline Gomphidae & 1 & $\mathrm{R}$ & 1 & $\mathrm{C}$ \\
\hline \multicolumn{5}{|c|}{ ODONATA (Zygoptera) } \\
\hline Coenagrionidae & 2 & $\mathrm{C}$ & 1 & $\mathrm{R}$ \\
\hline \multicolumn{5}{|l|}{ COLEOPTERA } \\
\hline Dryopidae & & & 1 & $\mathrm{R}$ \\
\hline Dytiscidae & 1 & $\mathrm{R}$ & 1 & $\mathrm{R}$ \\
\hline Elmidae & 1 & $\mathrm{C}$ & & \\
\hline Psephenidae & 1 & $\mathrm{C}$ & & \\
\hline \multicolumn{5}{|l|}{ HEMIPTERA } \\
\hline Gerridae & 1 & $\mathrm{R}$ & 1 & $\mathrm{R}$ \\
\hline Veliidae & 1 & $\mathrm{R}$ & 1 & $\mathrm{C}$ \\
\hline \multicolumn{5}{|l|}{ MEGALOPTERA } \\
\hline Corydalidae & 1 & $\mathrm{R}$ & 1 & $\mathrm{R}$ \\
\hline \multicolumn{5}{|l|}{ TOLERANT TAXA } \\
\hline OLIGOCHAETA & 2 & $\mathrm{R}$ & 2 & $\mathrm{C}$ \\
\hline ISOPODA & 1 & $\mathrm{R}$ & & \\
\hline CHIRONOMIDAE & 3 & $\mathrm{C}$ & 2 & $\mathrm{C}$ \\
\hline
\end{tabular}




\begin{tabular}{|l|c|c|c|c|}
\hline \multicolumn{1}{|c|}{ Taxa } & \multicolumn{2}{c|}{2011 (pre-mitigation) } & \multicolumn{2}{c|}{2012 (post-mitigation) } \\
\hline SIMULIIDAE & No. of Taxa & Density & No. of Taxa & Density $^{1}$ \\
\hline & 1 & $\mathrm{~A}$ & & \\
\hline DECAPODA & 1 & & & $\mathrm{C}$ \\
\hline & & $\mathrm{C}$ & 1 & \\
\hline GASTROPODA & & & & $\mathrm{A}$ \\
\hline Pleuroceridae & 3 & $\mathrm{C}$ & 2 & \\
\hline & & & & $\mathrm{R}$ \\
\hline BIVALVIA & 1 & $\mathrm{R}$ & 1 & $\mathrm{R}$ \\
\hline Corbiculidae & & & 1 & \\
\hline Sphaeriidae & & & & $\mathrm{C}$ \\
\hline & 1 & $\mathrm{R}$ & 1 & \\
\hline HYDRACARINA & & & & \\
\hline
\end{tabular}

${ }^{\mathrm{R}} \mathrm{R}=\mathrm{RARE}(<10), \mathrm{C}=\mathrm{COMMON}(10-100), \mathrm{A}=$ ABUNDANT $(>100)$

There was an increase in the number of taxa present in White Oak Creek in $2012(\mathrm{~N}=25)$, in comparison to 2011 ( $\mathrm{N}=22$ ). Overall, more of the taxa in 2012 fall under the category of abundant or common, so there is a greater abundance present for some of the taxa present in the creek. As with the survey results in First Creek Reach, such fluctuation is considered normal in annual surveys.

\subsection{Fish Communities}

Fish community sampling has been routinely conducted twice a year (spring and fall) in both First Creek and White Oak Creek as part of the BMAP program. The results presented here are post-mitigation for First Creek and White Oak Creek.

First Creek sampling has been conducted both downstream (FCK 0.1) and upstream (FCK 0.8) of the mitigated reach. In past sampling, the number of fish species downstream of the site tended to be similar or lower then reference streams. Results of recent sampling (March-May 2012) have shown the number of species to be lower downstream than in either reference stream. The number of fish species recorded upstream was also lower than reference streams, which has held true in the past as well. Fish densities for both downstream and upstream locations fell between those recorded for reference streams (Tables 9 and 10).

Overall, the 2012 survey indicated a decrease in the number of species present in both sections of First Creek. The densities were similar to those recorded in 2011, and there was an increase in biomass found in both sections.

White Oak Creek sampling has been conducted in the eastern third (WCK 4.4) of the mitigated reach. Past surveys have shown the number of fish species in the reach have tended to be lower than for reference streams. The results of recent sampling (October-December 2011, MarchMay 2012), indicate that this trend remains the case. The fish density found in White Oak Creek was between those recorded for reference streams, and the biomass of fish was lower than the reference streams (Tables 9 and 10). 
The 2012 survey indicated a slight increase in the number of species and fish density present in the sampling area in White Oak Creek from what was recorded in 2011, with a larger increase in biomass found in the creek.

Table 9. Fish species, density (fish $\left./ \mathrm{m}^{2}\right)$, and biomass $\left(\mathrm{g} \mathrm{fish} / \mathrm{m}^{2}\right)$ in parenthesis, in First Creek, White Oak Creek, and reference sites, Mill Branch and Ish Creek, October-December 2011.

\begin{tabular}{|c|c|c|c|c|c|}
\hline \multirow{2}{*}{ Species } & \multicolumn{5}{|c|}{ Sites $^{\mathrm{a}}$} \\
\hline & FCK 0.1 & FCK 0.8 & WCK 4.4 & MBK 1.6 & ISK 1.0 \\
\hline $\begin{array}{l}\text { Largescale stoneroller } \\
\text { (Campostoma oligolepis) }\end{array}$ & $\begin{array}{c}0.24 \\
(0.19)\end{array}$ & - & $\begin{array}{c}0.15 \\
(0.28)\end{array}$ & $\begin{array}{c}0.01 \\
(0.13)\end{array}$ & $\begin{array}{c}0.66 \\
(2.38)\end{array}$ \\
\hline $\begin{array}{l}\text { Spotfin shiner } \\
\text { (Cyprinella spiloptera) }\end{array}$ & - & - & - & - & $\begin{array}{c}0.01 \\
(0.05)\end{array}$ \\
\hline $\begin{array}{l}\text { Striped shiner } \\
\text { (Luxilus chrysocephalus) }\end{array}$ & $\begin{array}{c}0.24 \\
(0.31)\end{array}$ & - & - & $\begin{array}{c}0.03 \\
(0.47)\end{array}$ & $\begin{array}{c}2.69 \\
(6.79)\end{array}$ \\
\hline $\begin{array}{l}\text { Tennessee dace } \\
\text { (Chrosomus tennesseensis) }\end{array}$ & - & - & - & $\begin{array}{l}<0.01 \\
(0.01)\end{array}$ & $\begin{array}{l}<0.01 \\
(0.01)\end{array}$ \\
\hline $\begin{array}{l}\text { Bluntnose minnow } \\
\text { (Pimephales notatus) }\end{array}$ & $\begin{array}{c}1.83 \\
(2.41)\end{array}$ & $\begin{array}{c}1.19 \\
(2.47)\end{array}$ & - & - & $\begin{array}{c}3.54 \\
(7.07)\end{array}$ \\
\hline $\begin{array}{l}\text { Western blacknose dace } \\
\text { Rhinichthys obtusus }\end{array}$ & - & - & $\begin{array}{c}0.69 \\
(1.11)\end{array}$ & $\begin{array}{c}0.22 \\
(0.67)\end{array}$ & $\begin{array}{c}0.04 \\
(0.08)\end{array}$ \\
\hline $\begin{array}{l}\text { Creek chub } \\
\text { (Semotilus atromaculatus) }\end{array}$ & - & - & - & $\begin{array}{c}0.12 \\
(1.08)\end{array}$ & $\begin{array}{c}0.04 \\
(0.45)\end{array}$ \\
\hline $\begin{array}{l}\text { White sucker } \\
\text { (Catostomus commersonii) }\end{array}$ & - & - & - & $\begin{array}{c}0.01 \\
(0.18)\end{array}$ & - \\
\hline $\begin{array}{l}\text { Northern hogsucker } \\
\text { (Hypentelium nigricans) }\end{array}$ & - & - & - & $\begin{array}{l}<0.01 \\
(0.16)\end{array}$ & - \\
\hline $\begin{array}{l}\text { Western mosquitofish } \\
\text { (Gambusia affinis) }\end{array}$ & $\begin{array}{c}0.18 \\
(0.04)\end{array}$ & - & - & - & - \\
\hline $\begin{array}{l}\text { Banded sculpin } \\
\text { (Cottus carolinae) }\end{array}$ & $\begin{array}{c}0.02 \\
(0.17)\end{array}$ & $\begin{array}{c}0.17 \\
(0.85)\end{array}$ & - & - & $\begin{array}{c}0.03 \\
(0.21)\end{array}$ \\
\hline $\begin{array}{l}\text { Redbreast sunfish } \\
\text { (Lepomis auritus) }\end{array}$ & - & - & $\begin{array}{c}0.03 \\
(0.37)\end{array}$ & - & $\begin{array}{c}0.25 \\
(1.59)\end{array}$ \\
\hline $\begin{array}{l}\text { Green sunfish } \\
\text { (Lepomis cyanellus) }\end{array}$ & $\begin{array}{c}0.02 \\
(0.33)\end{array}$ & - & - & - & $\begin{array}{l}0.25 \\
(1.53)\end{array}$ \\
\hline $\begin{array}{l}\text { Warmouth } \\
\text { (Lepomis gulosus) }\end{array}$ & - & - & - & $\begin{array}{c}0.02 \\
(0.48)\end{array}$ & - \\
\hline $\begin{array}{l}\text { Bluegill } \\
\text { (Lepomis macrochirus) }\end{array}$ & $\begin{array}{c}0.02 \\
(0.21)\end{array}$ & - & $\begin{array}{c}0.01 \\
(0.05)\end{array}$ & $\begin{array}{c}0.22 \\
(0.86)\end{array}$ & $\begin{array}{c}0.07 \\
(0.36)\end{array}$ \\
\hline $\begin{array}{l}\text { Spotted bass } \\
\text { (Micropterus punctulatus.) }\end{array}$ & - & - & - & $\begin{array}{l}<0.01 \\
(0.01)\end{array}$ & - \\
\hline $\begin{array}{l}\text { Stripetail darter } \\
\text { (Etheostoma kennicotti) }\end{array}$ & - & - & - & $\begin{array}{c}0.05 \\
(0.07)\end{array}$ & - \\
\hline $\begin{array}{l}\text { Snubnose darter } \\
\text { (Etheostoma simoterum) }\end{array}$ & - & - & - & - & $\begin{array}{c}0.19 \\
(0.34) \\
\end{array}$ \\
\hline $\begin{array}{l}\text { Number of species }(\mathbf{N}) \\
\text { Density } \\
\text { Biomass }\end{array}$ & $\begin{array}{c}7 \\
2.57 \\
(3.66)\end{array}$ & $\begin{array}{c}2 \\
1.36 \\
(2.32)\end{array}$ & $\begin{array}{c}4 \\
0.88 \\
(1.81)\end{array}$ & $\begin{array}{c}11 \\
0.68 \\
(4.12)\end{array}$ & $\begin{array}{c}12 \\
7.77 \\
(20.86)\end{array}$ \\
\hline
\end{tabular}

${ }^{\mathrm{a}} \mathrm{WCK}=$ White Oak Creek kilometer; MBK = Mill Branch kilometer; ISK = Ish Creek kilometer, FCK = First Creek kilometer. 
Table 10. Fish species, density $\left(\mathrm{fish} / \mathrm{m}^{2}\right)$, and biomass $\left(\mathrm{g}\right.$ fish $\left./ \mathrm{m}^{2}\right)$ in parenthesis, in First Creek, White Oak Creek, and reference sites, Mill Branch and Ish Creek, March-May 2012.

\begin{tabular}{|c|c|c|c|c|c|}
\hline \multirow{2}{*}{ Species } & \multicolumn{5}{|c|}{ Sites $^{\mathrm{a}}$} \\
\hline & FCK 0.1 & FCK 0.8 & WCK 4.4 & MBK 1.6 & ISK 1.0 \\
\hline $\begin{array}{l}\text { Largescale stoneroller } \\
\text { (Campostoma oligolepis) }\end{array}$ & $\begin{array}{c}0.15 \\
(0.37)\end{array}$ & - & $\begin{array}{c}0.56 \\
(0.68)\end{array}$ & $\begin{array}{c}0.01 \\
(0.34)\end{array}$ & $\begin{array}{c}0.21 \\
(1.04)\end{array}$ \\
\hline $\begin{array}{l}\text { Striped shiner } \\
\text { (Luxilus chrysocephalus) }\end{array}$ & $\begin{array}{c}0.20 \\
(0.82)\end{array}$ & - & $\begin{array}{c}0.07 \\
(0.65)\end{array}$ & $\begin{array}{c}0.12 \\
(1.45)\end{array}$ & $\begin{array}{l}0.65 \\
(2.56)\end{array}$ \\
\hline $\begin{array}{l}\text { Tennessee dace } \\
\text { (Chrosomus tennesseensis) }\end{array}$ & - & - & - & $\begin{array}{c}0.01 \\
(<0.01)\end{array}$ & $\begin{array}{c}0.01 \\
(0.01)\end{array}$ \\
\hline $\begin{array}{l}\text { Bluntnose minnow } \\
\text { (Pimephales notatus) }\end{array}$ & - & - & - & - & $\begin{array}{c}0.03 \\
(0.05)\end{array}$ \\
\hline $\begin{array}{l}\text { Western blacknose dace } \\
\text { (Rhinichthys obtusus) }\end{array}$ & $\begin{array}{c}1.77 \\
(3.59)\end{array}$ & $\begin{array}{c}1.42 \\
(2.85)\end{array}$ & $\begin{array}{c}0.60 \\
(1.48)\end{array}$ & $\begin{array}{c}0.19 \\
(0.79)\end{array}$ & $\begin{array}{c}0.05 \\
(0.13)\end{array}$ \\
\hline $\begin{array}{l}\text { Creek chub } \\
\text { (Semotilus atromaculatus) }\end{array}$ & - & - & - & $\begin{array}{c}0.13 \\
(1.10)\end{array}$ & $\begin{array}{c}0.05 \\
(0.42)\end{array}$ \\
\hline $\begin{array}{l}\text { White sucker } \\
\text { (Catostomus commersonii) }\end{array}$ & - & - & - & $\begin{array}{c}0.02 \\
(0.96)\end{array}$ & $\begin{array}{c}0.01 \\
(0.13)\end{array}$ \\
\hline $\begin{array}{l}\text { Northern hogsucker } \\
\text { (Hypentelium nigricans) }\end{array}$ & - & - & - & $\begin{array}{c}0.01 \\
(0.22)\end{array}$ & - \\
\hline $\begin{array}{l}\text { Western mosquitofish } \\
\text { (Gambusia affinis) }\end{array}$ & $\begin{array}{c}0.17 \\
(0.09)\end{array}$ & - & - & - & - \\
\hline $\begin{array}{l}\text { Banded sculpin } \\
\text { (Cottus carolinae) }\end{array}$ & - & $\begin{array}{c}0.16 \\
(0.52)\end{array}$ & $\begin{array}{c}0.01 \\
(0.05)\end{array}$ & - & $\begin{array}{c}0.59 \\
(3.46)\end{array}$ \\
\hline $\begin{array}{l}\text { Redbreast sunfish } \\
\text { (Lepomis auritus) }\end{array}$ & - & - & $\begin{array}{c}0.05 \\
(0.76)\end{array}$ & - & $\begin{array}{c}0.10 \\
(0.59)\end{array}$ \\
\hline $\begin{array}{l}\text { Green sunfish } \\
\text { (Lepomis cyanellus) }\end{array}$ & - & - & - & - & $\begin{array}{c}0.31 \\
(2.17)\end{array}$ \\
\hline $\begin{array}{l}\text { Warmouth } \\
\text { (Lepomis gulosus) }\end{array}$ & - & - & - & $\begin{array}{c}0.02 \\
(0.23)\end{array}$ & - \\
\hline $\begin{array}{l}\text { Bluegill } \\
\text { (Lepomis macrochirus) }\end{array}$ & - & - & - & $\begin{array}{c}0.47 \\
(0.83)\end{array}$ & - \\
\hline $\begin{array}{l}\text { Largemouth bass } \\
\text { (Micropterus salmoides) }\end{array}$ & - & - & - & $\begin{array}{c}0.01 \\
(0.04)\end{array}$ & - \\
\hline $\begin{array}{l}\text { Blackside snubnose darter } \\
\text { (Etheostoma duryi) }\end{array}$ & - & - & - & - & $\begin{array}{c}0.01 \\
(0.01)\end{array}$ \\
\hline $\begin{array}{l}\text { Stripetail darter } \\
\text { (Etheostoma kennicotti) }\end{array}$ & - & - & - & $\begin{array}{c}0.06 \\
(0.10)\end{array}$ & - \\
\hline $\begin{array}{l}\text { Snubnose darter } \\
\text { (Etheostoma simoterum) }\end{array}$ & - & - & - & - & $\begin{array}{c}0.33 \\
(0.55)\end{array}$ \\
\hline Number of species $(\mathbf{N})$ & 4 & 2 & 5 & 11 & 12 \\
\hline Density & 2.29 & 1.58 & 1.29 & 1.05 & 2.35 \\
\hline Biomass & 4.87 & 3.37 & 3.62 & 6.06 & 11.12 \\
\hline
\end{tabular}

${ }^{\mathrm{a}} \mathrm{WCK}=$ White Oak Creek kilometer; MBK = Mill Branch kilometer; ISK = Ish Creek kilometer, FCK = First Creek kilometer. 


\subsection{CONCLUSIONS}

\subsection{ORNL Parking Structure Wetland (P2)}

Baseline data obtained for the $\mathrm{P} 2$ wetland showed sparse vegetation with limited habitat prior to mitigation. Despite this, volunteer wetland plants had already become established on the site, providing a good initial start to the recovery of the wetland. The relatively marginal habitat present on the site was evident in the lack of fauna recorded during initial surveys. Supplemental planting conducted on the site with native wetland plants in June 2011 was expected to significantly improve the quality of these wetlands. The first year of post-mitigation monitoring for this site in 2012 suggests that there is indeed an improvement in habitat quality, as there is a diversity of wetland plants, and a significant increase in vegetation cover with little bare ground present in the wetland. The presence of a moderately diverse assemblage of fauna living in and around the wetland also indicates a more diverse habitat as a result of mitigation.

\subsection{First Creek}

The results of habitat measurements conducted in 2012 along this reach of First Creek showed that the creek provided good overall habitat and was in a non-impaired state. The relatively linear condition of the creek was evidence of past channelization with the development of the area. Relatively narrow riparian zones are a weakness of the site from the perspective of providing good quality habitat. However, riparian zones in this area are restricted by paved and landscaped areas being that the creek runs through a developed area. Mitigation plantings on the east side of the creek have improved habitat quality in that area over original habitat conditions that included large mowed turf grass areas and a high number of invasive plant species. The riparian zone on the west side is highly restricted due to the close proximity of landscaped and parking areas associated with a building complex. Cover is maintained to the maximum extent possible in this narrow zone. The presence of invasive plants in these zones, such as winter creeper and Johnson grass (growing on both sides) is a potential concern.

While there was some mortality of mitigation plantings found along the First Creek reach during the 2012 survey, overall survivorship of east side riparian plantings still appears to be very good. The cause of plant mortality is thought to be partially associated with the unusually high temperatures and short-term drought that occurred during the time of the survey. Replanting will occur in order to replace some of the plants lost, to assure that good vegetation cover is maintained. Dense growths of shrubs (e.g., silky dogwood, spicebush) previously existing on the site continue to provide significant cover along the creek banks, particularly along northern portions of the study area. Overall conditions at the site related to vegetation growth and success remain very good.

A moderately diverse benthic macroinvertebrate population was recorded at the site in 2012 . This included taxa typically found in clear streams. Fish population (sampled upstream and downstream of the site) densities were similar to certain reference streams on the ORR. The number of fish species at both the downstream and upstream sampling locations was lower than reference streams. 
The third year of post-mitigation monitoring for this site will be conducted in the summer of 2013.

\subsection{White Oak Creek}

The results of habitat measurements conducted along this reach of White Oak Creek in 2011 showed that the creek provided average overall habitat in the pre-mitigation condition and was in a non-impaired state, a rating that was maintained in 2012. Epifaunal substrate was somewhat lacking in the presence of logs and snags; however, the creek provided numerous riffles, some undercut banks, a variety of particle sizes and overhanging branches. One velocity/depth regime (fast-deep) was missing from the reach. Channel alteration from past development of the area was evident along some areas of the reach. Vegetative protection at the banks was compromised by the presence invasive plant species (i.e., winter creeper, Japanese honeysuckle, Nepal grass, and Johnson grass) in 2011. However, significant improvements were noted in 2012 due to removal of invasives and replacement with native plants during mitigation. Narrow riparian zones were a significant weakness on the site prior to mitigation, mainly due to the existence of adjacent areas that contained large areas of low turf grasses and weedy species. Although riparian zone width is restricted on the north side by an existing paved road and on the south side by a building, modifications made to the site with the mitigation planting has resulted in a significant increase in the width and quality of the vegetative riparian zone.

The site, pre-mitigation, displayed good vegetation cover. However, much of the area was covered by either managed/mowed turf areas or non-native invasive plant species. This year showed a decrease in the percentage of ground covered by invasive plants and turf grass, with an increase in diversity of native wetland plants. Overall survivorship of the plantings was good, with few unhealthy or dead plants found.

A moderately diverse benthic macroinvertebrate population was recorded at the site in 2012 , with an increase in the number of taxa from 2011. This included some of the more tolerant taxa found in ORR streams. Fish population (sampled within the reach) densities were similar to certain reference streams on the ORR. The number of fish species recorded was lower than those found in the reference streams.

The second year of post-mitigation monitoring for this site will be conducted in the summer of 2013. 


\subsection{REFERENCES}

Barbour, M. T., J. Gerritsen, B. D. Snyder and J. B. Stribling. 1999. Rapid Bioassessment Protocols for Use in Streams and Wadeable Rivers: Periphyton, Bethic Macroinvertebrates, and Fish, Second Addition. EPA 841-B-99-002. U.S. Environmental Protection Agency; Office of Water; Washington, D.C.

Giffen, N.R., M.G. Ryon and R.T. Jett. 2011. ORNL Parking Structure Mitigation Report. Unpublished report.

Niemi, G. J., P. DeVore, N. Detenbeck, D. Taylor, A. Lima, J. Pastor, J. D. Yount, and R. J. Naiman. 1990. Overview of case studies on recovery of aquatic systems from disturbance. Environ. Manag. 15(5):571-588.

Ryon, M. G. 2011. Recovery of fish communities in a warm water stream following pollution abatement. Environ. Manag. 47(6):1096-1111.

Ryon, M .G. and H. D. Quarles. 2008. Considerations associated with landscaping of First Creek riparian buffer and installation of new pedestrian bridge. Unpublished report. 
(THIS PAGE LEFT BLANK INTENTIONALLY) 
APPENDIX A - HABITAT ASSESSMENT FORM 


\section{HABITAT ASSESSMENT FIELD DATA SHEET-HIGH GRADIENT STREAMS (FRONT)}

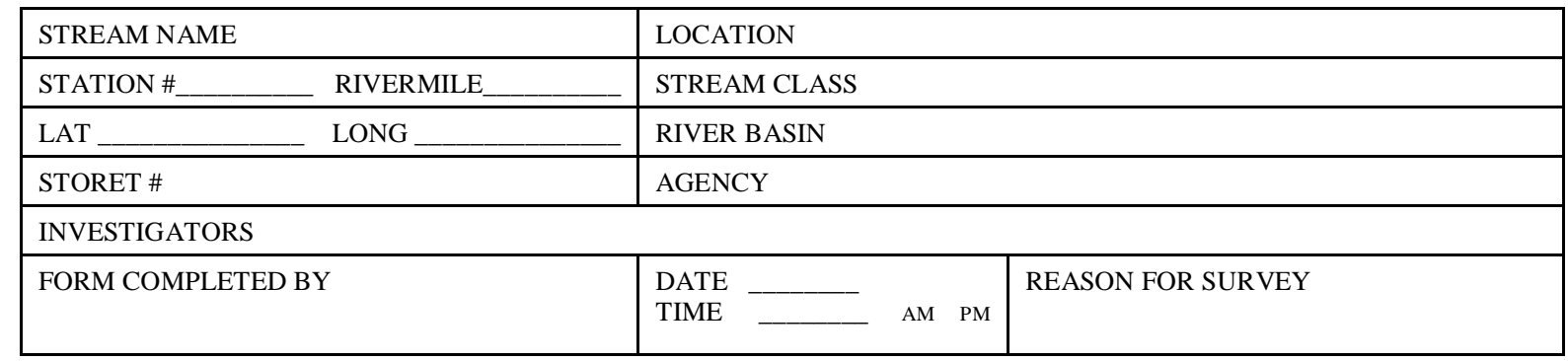

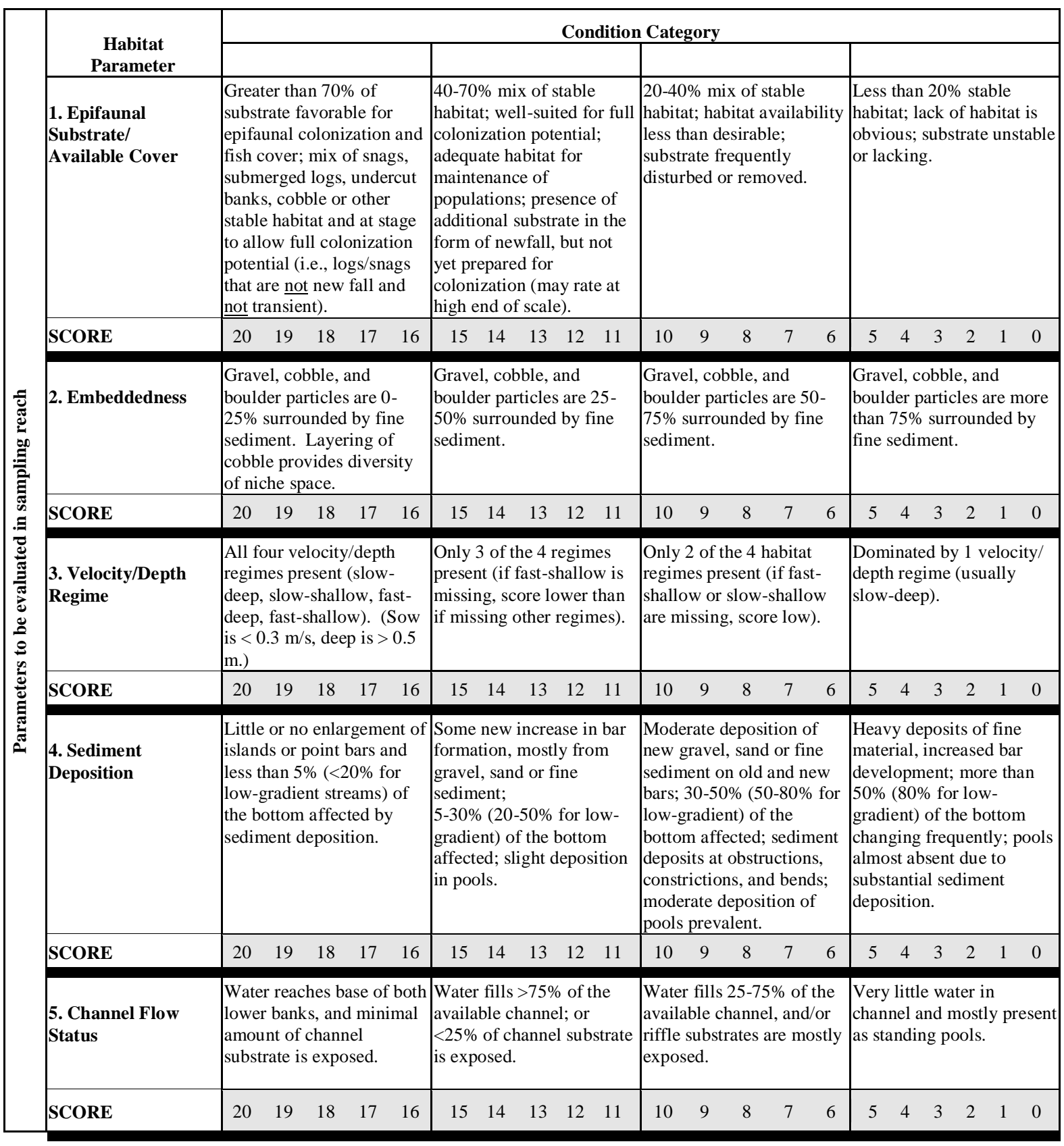




\begin{tabular}{|c|c|c|c|c|}
\hline \multirow{2}{*}{$\begin{array}{c}\text { Habitat } \\
\text { Parameter }\end{array}$} & \multicolumn{4}{|c|}{ Condition Category } \\
\hline & & & & \\
\hline $\begin{array}{l}\text { 6. Channel } \\
\text { Alteration }\end{array}$ & $\begin{array}{l}\text { Channelization or } \\
\text { dredging absent or } \\
\text { minimal; stream with } \\
\text { normal pattern. }\end{array}$ & $\begin{array}{l}\text { Some channelization } \\
\text { present, usually in areas of } \\
\text { bridge abutments; } \\
\text { evidence of past } \\
\text { channelization, i.e., } \\
\text { dredging, (greater than } \\
\text { past } 20 \text { yr) may be present, } \\
\text { but recent channelization } \\
\text { is not present. } \\
\end{array}$ & $\begin{array}{l}\text { Channelization may be } \\
\text { extensive; embankments } \\
\text { or shoring structures } \\
\text { present on both banks; and } \\
40 \text { to } 80 \% \text { of stream reach } \\
\text { channelized and disrupted. } \\
\end{array}$ & $\begin{array}{l}\text { Banks shored with gabion } \\
\text { or cement; over } 80 \% \text { of the } \\
\text { stream reach channelized } \\
\text { and disrupted. Instream } \\
\text { habitat greatly altered or } \\
\text { removed entirely. }\end{array}$ \\
\hline SCORE & $\begin{array}{lllll}20 & 19 & 18 & 17 & 16\end{array}$ & $\begin{array}{lllll}15 & 14 & 13 & 12 & 11\end{array}$ & $10 \quad 9$ & $\begin{array}{lll}2 & 1 & 0\end{array}$ \\
\hline $\begin{array}{l}\text { 7. Frequency of } \\
\text { Riffles (or bends) }\end{array}$ & $\begin{array}{l}\text { Occurrence of riffles } \\
\text { relatively frequent; ratio of } \\
\text { distance between riffles } \\
\text { divided by width of the } \\
\text { stream <7:1 (generally } 5 \text { to } \\
\text { 7); variety of habitat is } \\
\text { key. In streams where } \\
\text { riffles are continuous, } \\
\text { placement of boulders or } \\
\text { other large, natural } \\
\text { obstruction is important. } \\
\end{array}$ & $\begin{array}{l}\text { Occurrence of riffles } \\
\text { infrequent; distance } \\
\text { between riffles divided by } \\
\text { the width of the stream is } \\
\text { between } 7 \text { to } 15 .\end{array}$ & $\begin{array}{l}\text { Occasional riffle or bend; } \\
\text { bottom contours provide } \\
\text { some habitat; distance } \\
\text { between riffles divided by } \\
\text { the width of the stream is } \\
\text { between } 15 \text { to } 25 \text {. }\end{array}$ & $\begin{array}{l}\text { Generally all flat water or } \\
\text { shallow riffles; poor } \\
\text { habitat; distance between } \\
\text { riffles divided by the width } \\
\text { of the stream is a ratio of } \\
>25 \text {. }\end{array}$ \\
\hline SCORE & $\begin{array}{lllll}20 & 19 & 18 & 17 & 16\end{array}$ & $\begin{array}{lllll}15 & 14 & 13 & 12 & 11\end{array}$ & $\begin{array}{lllll}10 & 9 & 8 & 7 & 6\end{array}$ & $\begin{array}{lllll}5 & 4 & 3 & 2 & 1\end{array}$ \\
\hline $\begin{array}{l}\text { 8. Bank Stability } \\
\text { (score each bank) } \\
\text { Note: determine left } \\
\text { or right side by facing } \\
\text { downstream. }\end{array}$ & $\begin{array}{l}\text { Banks stable; evidence of } \\
\text { erosion or bank failure } \\
\text { absent or minimal; little } \\
\text { potential for future } \\
\text { problems. }<5 \% \text { of bank } \\
\text { affected. }\end{array}$ & $\begin{array}{l}\text { Moderately stable; } \\
\text { infrequent, small areas of } \\
\text { erosion mostly healed } \\
\text { over. 5-30\% of bank in } \\
\text { reach has areas of erosion. }\end{array}$ & $\begin{array}{l}\text { Moderately unstable; } 30- \\
60 \% \text { of bank in reach has } \\
\text { areas of erosion; high } \\
\text { erosion potential during } \\
\text { floods. }\end{array}$ & $\begin{array}{l}\text { Unstable; many eroded } \\
\text { areas; "raw" areas frequent } \\
\text { along straight sections and } \\
\text { bends; obvious bank } \\
\text { sloughing; } 60-100 \% \text { of } \\
\text { bank has erosional scars. }\end{array}$ \\
\hline SCORE___ (LB) & Left Bank 10 & 7 & 4 & 2 \\
\hline SCORE___ $(\mathrm{RB})$ & Right Bank 10 & 7 & 4 & 2 \\
\hline $\begin{array}{l}\text { 9. Vegetative } \\
\text { Protection (score } \\
\text { each bank) }\end{array}$ & $\begin{array}{l}\text { More than } 90 \% \text { of the } \\
\text { streambank surfaces and } \\
\text { immediate riparian zone } \\
\text { covered by native } \\
\text { vegetation, including trees, } \\
\text { understory shrubs, or } \\
\text { nonwoody macrophytes; } \\
\text { vegetative disruption } \\
\text { through grazing or } \\
\text { mowing minimal or not } \\
\text { evident; almost all plants } \\
\text { allowed to grow naturally. }\end{array}$ & $\begin{array}{l}70-90 \% \text { of the streambank } \\
\text { surfaces covered by native } \\
\text { vegetation, but one class of } \\
\text { plants is not well- } \\
\text { represented; disruption } \\
\text { evident but not affecting } \\
\text { full plant growth potential } \\
\text { to any great extent; more } \\
\text { than one-half of the } \\
\text { potential plant stubble } \\
\text { height remaining. }\end{array}$ & $\begin{array}{l}50-70 \% \text { of the streambank } \\
\text { surfaces covered by } \\
\text { vegetation; disruption } \\
\text { obvious; patches of bare } \\
\text { soil or closely cropped } \\
\text { vegetation common; less } \\
\text { than one-half of the } \\
\text { potential plant stubble } \\
\text { height remaining. }\end{array}$ & $\begin{array}{l}\text { Less than } 50 \% \text { of the } \\
\text { streambank surfaces } \\
\text { covered by vegetation; } \\
\text { disruption of streambank } \\
\text { vegetation is very high; } \\
\text { vegetation has been } \\
\text { removed to } \\
5 \text { centimeters or less in } \\
\text { average stubble height. }\end{array}$ \\
\hline SCORE___ (LB) & Left Bank 10 & 7 & 5 & 2 \\
\hline SCORE___ (RB) & Right Bank 10 & 6 & 4 & 1 \\
\hline $\begin{array}{l}\text { 10. Riparian } \\
\text { Vegetative Zone } \\
\text { Width (score each } \\
\text { bank riparian zone) }\end{array}$ & $\begin{array}{l}\text { Width of riparian zone }>18 \\
\text { meters; human activities } \\
\text { (i.e., parking lots, } \\
\text { roadbeds, clear-cuts, } \\
\text { lawns, or crops) have not } \\
\text { impacted zone. }\end{array}$ & $\begin{array}{l}\text { Width of riparian zone 12- } \\
18 \text { meters; human } \\
\text { activities have impacted } \\
\text { zone only minimally. }\end{array}$ & $\begin{array}{l}\text { Width of riparian zone 6- } \\
12 \text { meters; human } \\
\text { activities have impacted } \\
\text { zone a great deal. }\end{array}$ & $\begin{array}{l}\text { Width of riparian zone }<6 \\
\text { meters: little or no riparian } \\
\text { vegetation due to human } \\
\text { activities. }\end{array}$ \\
\hline SCORE ___ (LB) & Left Bank 10 & 7 & 4 & 2 \\
\hline SCORE ___ (RB) & Right Bank 10 & 7 & 4 & 1 \\
\hline
\end{tabular}

Total Score 
(THIS PAGE LEFT BLANK INTENTIONALLY) 
APPENDIX B - PLANTING PLAN FOR FIRST CREEK MITIGATION 


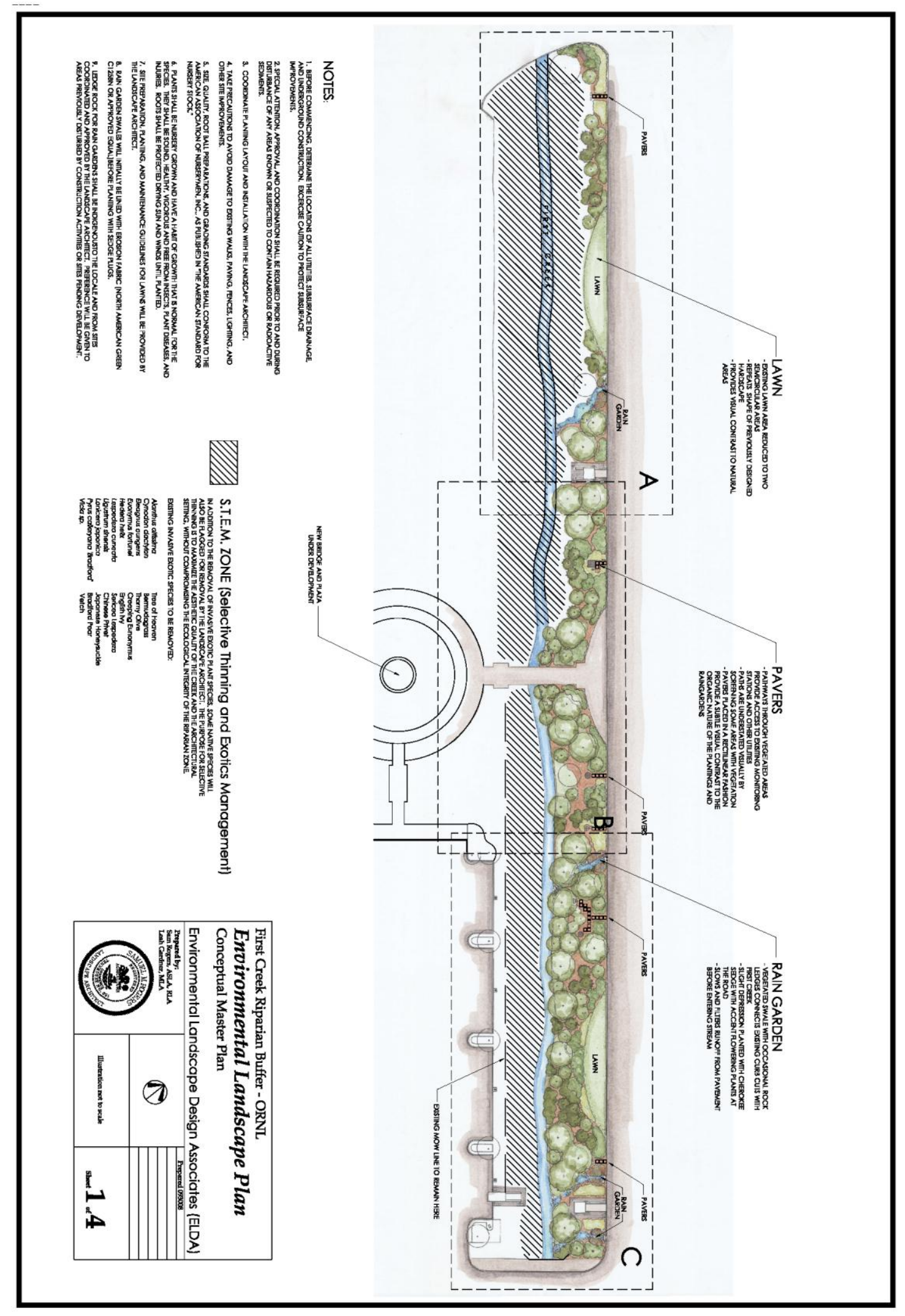




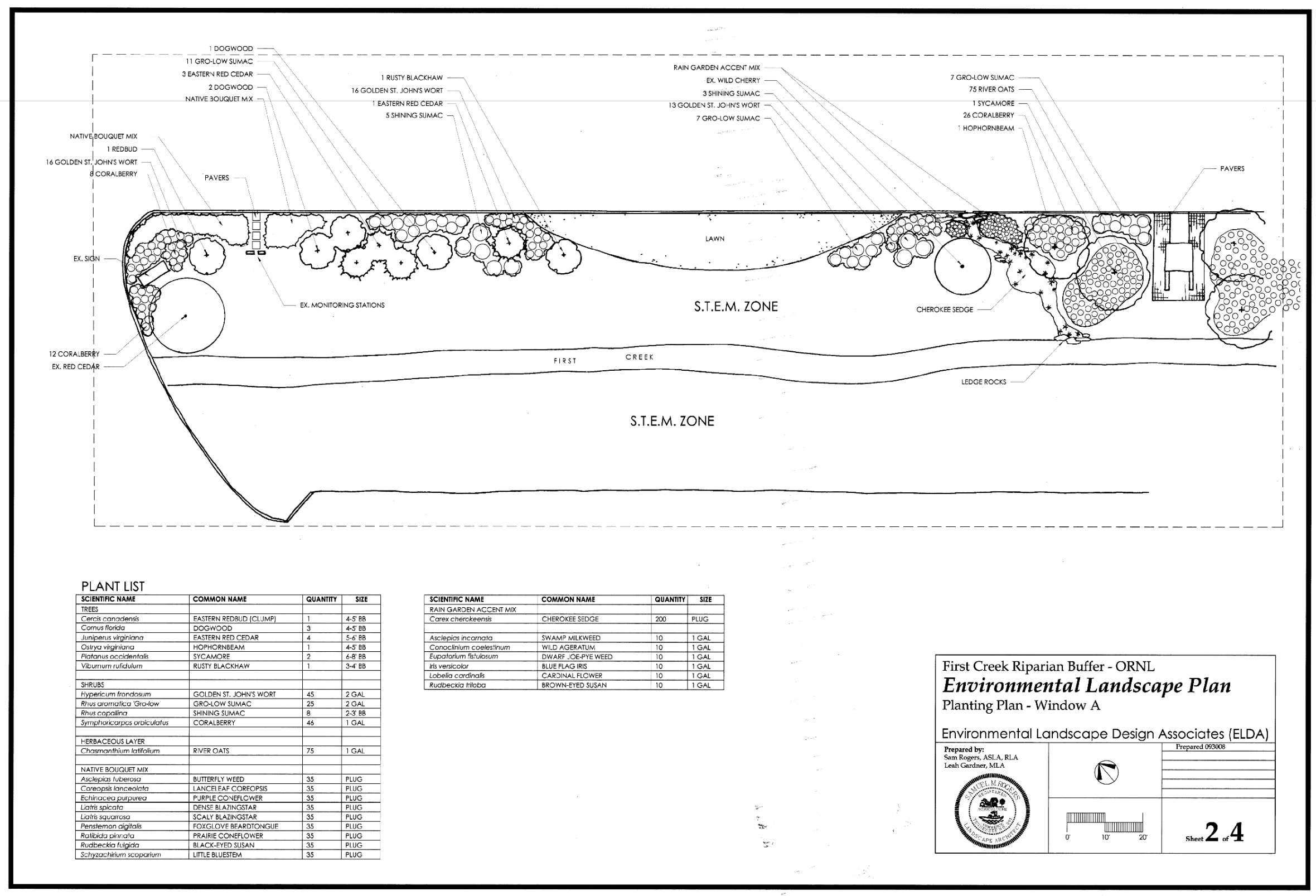




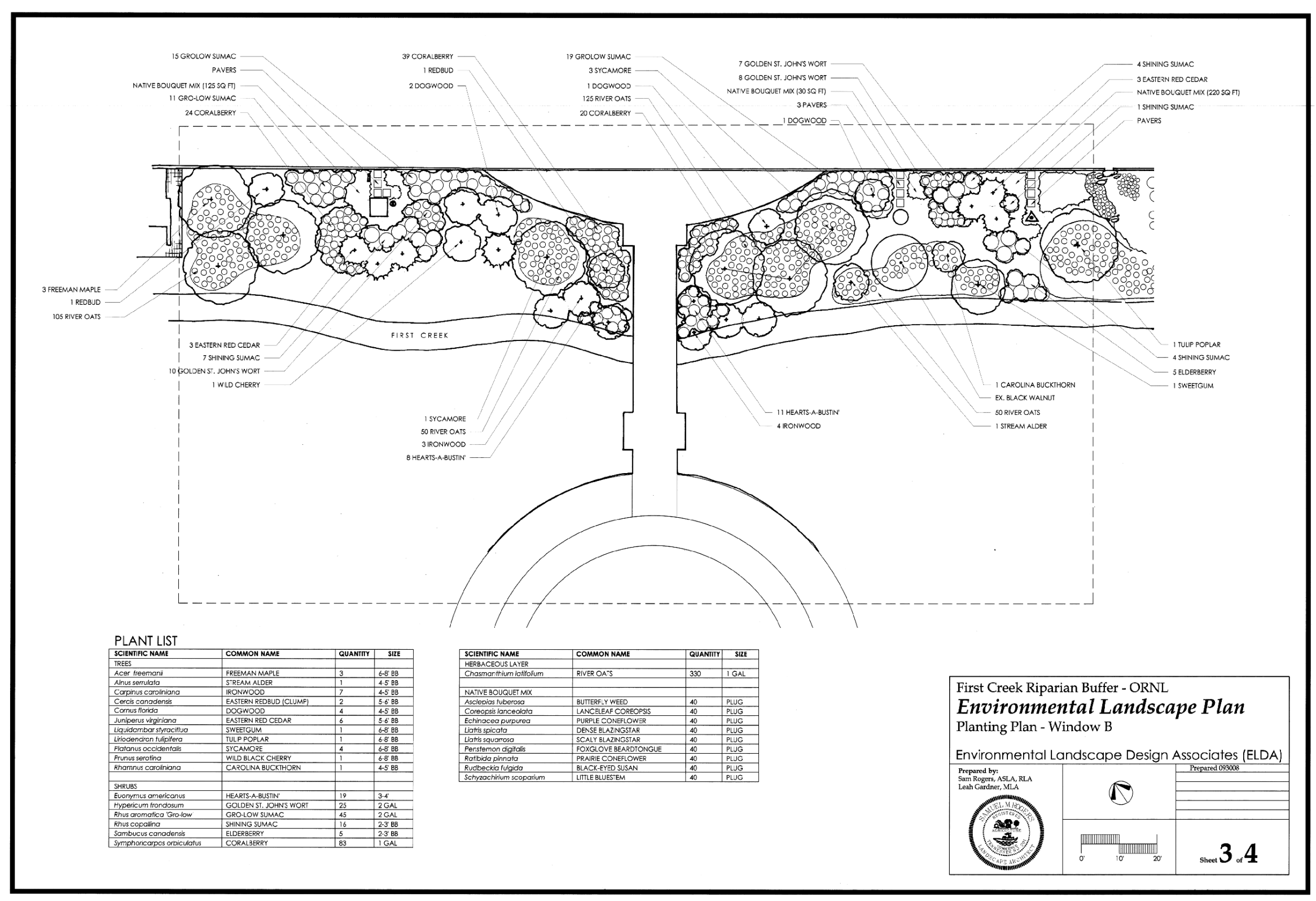




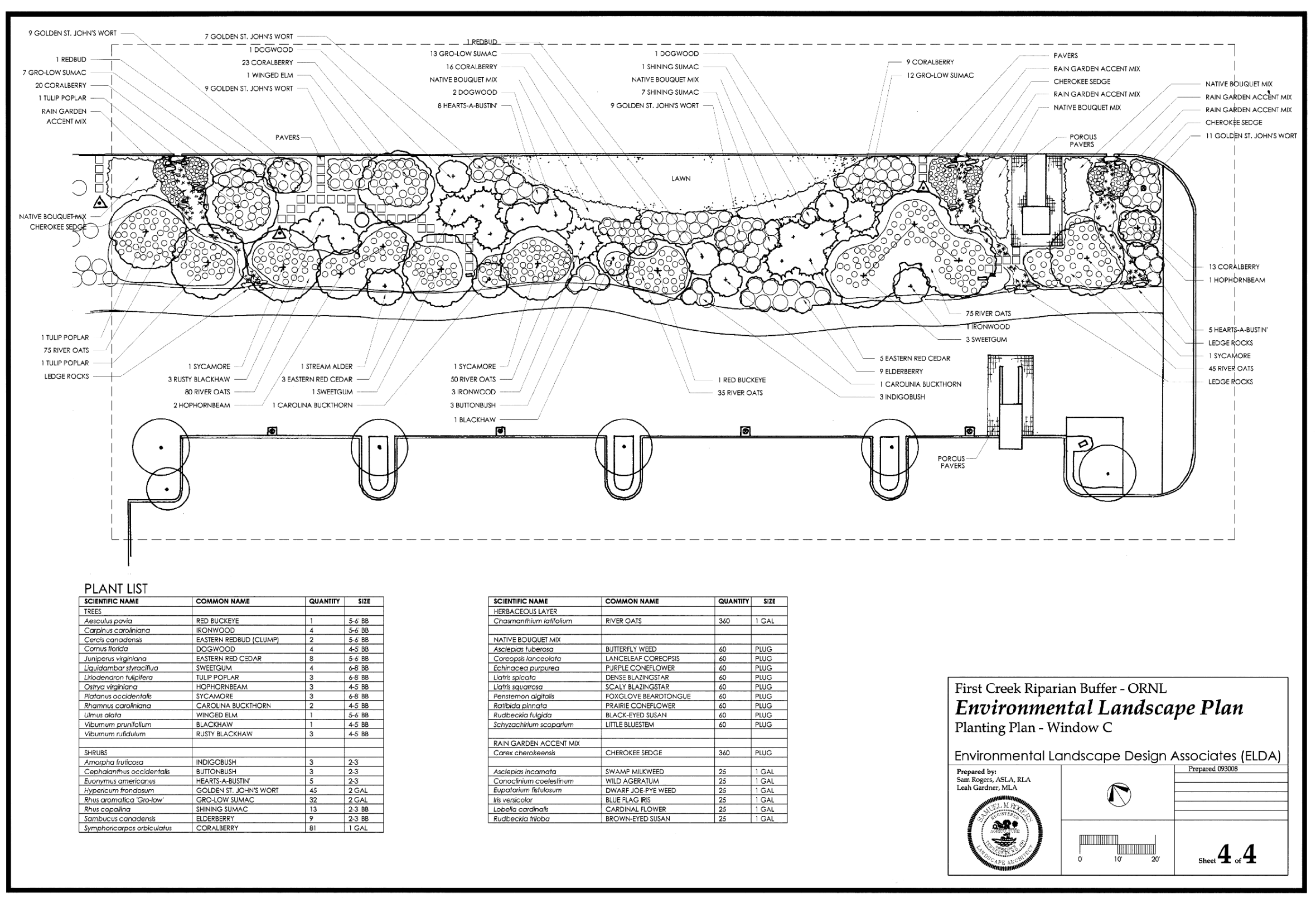


(THIS PAGE LEFT BLANK INTENTIONALLY) 
APPENDIX C - PLANT SPECIES LISTS FOR THE FIRST CREEK AND WHITE OAK CREEK REACHES 
Table C1. Plant Species List for the First Creek Reach (July 2012).

\begin{tabular}{|c|c|c|}
\hline \# & Scientific Name & Common Name \\
\hline 1 & Acer rubrum & Red maple \\
\hline 2 & Acer saccharinum & Silver maple \\
\hline 3 & Aster sp. & Aster \\
\hline 4 & Allium canadense & Wild Garlic \\
\hline 5 & Boehmeria cylindrical & False nettle \\
\hline 6 & Campsis radicans & Trumpet-creeper \\
\hline 7 & Carex cherokeensis & Cherokee sedge \\
\hline 8 & Carex frankii & Frank's sedge \\
\hline 9 & Carpinus caroliniana & Ironwood* \\
\hline 10 & Chasmanthium latifolium & River oats* \\
\hline 11 & Cirsium sp. & Thistle \\
\hline 12 & Coreopsis lanceolata & Lanceleaf coreopsis* \\
\hline 13 & Cornus florida & Flowering dogwood* \\
\hline 14 & Crataegus sp. & Hawthorne \\
\hline 15 & Cynodon dactylon & Bermuda grass \\
\hline 16 & Digitaria $s p$ & Crabgrass \\
\hline 17 & Dioscorea bulbifera & Air potato** \\
\hline 18 & Diospyros virginiana & Persimmon \\
\hline 19 & Echinacea purpurea & Eastern purple cornflower* \\
\hline 20 & Elaeagnus pungens & Thorny olive** \\
\hline 21 & Euonymus sp. & Winter creeper** \\
\hline 22 & Festuca sp. & Fescue \\
\hline 23 & Fraxinus pennsylvanica & Green ash \\
\hline 24 & Galium sp. & Bedstraw \\
\hline 25 & Hypericum densiflorum & Bushy St. John’s wort \\
\hline 26 & Hypericum frondosum & Golden St. John's wort* \\
\hline 27 & Ilex verticillata & Winterberry \\
\hline 28 & Impatiens sp. & Jewelweed \\
\hline 29 & Juglans nigra & Black walnut \\
\hline 30 & Juncus coriaceus & Leathery rush \\
\hline 31 & Juncus effusus & Soft rush \\
\hline 32 & Juncus tenuis & Path rush \\
\hline 33 & Juniperus virginiana & Eastern red cedar* \\
\hline 34 & Ligustrum sinensis & Chinese privet** \\
\hline 35 & Lindera benzoin & Common spicebush \\
\hline 36 & Liriodendron tulipifera & Tulip poplar* \\
\hline 37 & Ludwigia palustris & Evening primrose \\
\hline 38 & Lonicera japonica & Japanese honeysuckle** \\
\hline 39 & Mentha sp. & Mint \\
\hline 40 & Microstegium vimineum & Nepal grass $* *$ \\
\hline 41 & Parthenocissus quinquefolia & Virginia creeper \\
\hline 42 & Potentilla indica & Mock Strawberry** \\
\hline
\end{tabular}




\begin{tabular}{|l|l|l|}
\hline 43 & Prunus serotina & Black cherry* \\
\hline 44 & Ratibida pinnata & Prairie coneflower* \\
\hline 45 & Rhus aromatica & Gro-low sumac* \\
\hline 46 & Rhus copallina & Winged sumac \\
\hline 47 & Rubus argutus & Blackberry \\
\hline 48 & Rumex crispus & Curled dock \\
\hline 49 & Schizachyrium scoparium & Little bluestem* \\
\hline 50 & Securigera varia & Crown vetch** \\
\hline 51 & Sorghum halepense & Johnson grass** \\
\hline 52 & Solidago sp. & Goldenrod \\
\hline 53 & Sporobolus heterolepis & Prairie Dropseed \\
\hline 54 & Symphoricarpos orbiculatus & Coralberry* \\
\hline 55 & Toxicodendron radicans & Poison ivy \\
\hline 56 & Vernonia gigantea & Tall ironweed \\
\hline 57 & Viburnum sp. & Blackhaw* \\
\hline 58 & Vitis sp. & Grape \\
\hline
\end{tabular}

*Species on the mitigation planting list

**Exotic invasive species 
Table C2. Plant Species List for the White Oak Creek Reach (June 2012).

\begin{tabular}{|c|c|c|}
\hline \# & Scientific Name & Common Name \\
\hline 1 & Acer negundo & Box elder \\
\hline 2 & Allium canadense & Wild garlic \\
\hline 3 & Asclepias tuberosa & Butterfly weed* \\
\hline 4 & Barbarea verna & Early winter-cress \\
\hline 5 & Brassica rapa & Rape mustard \\
\hline 6 & Callicarpa americana & American beautyberry* \\
\hline 7 & Campsis radicans & Trumpet-creeper \\
\hline 8 & Carex cherokeensis & Cherokee sedge* \\
\hline 9 & Cephalanthus occidentalis & Buttonbush \\
\hline 10 & Cercis canadensis & Eastern redbud* \\
\hline 11 & Chasmanthium latifolium & River oats* \\
\hline 12 & Cirsium sp. & Thistle \\
\hline 13 & Cladrastis kentukea & American yellowwood* \\
\hline 14 & Coreopsis sp. & Tick-seed \\
\hline 15 & Cornus amomum & Silky dogwood \\
\hline 16 & Cornus florida & Flowering dogwood* \\
\hline 17 & Cynodon dactylon & Bermuda grass \\
\hline 18 & Dioscorea bulbifera & Air Potato** \\
\hline 19 & Diospyros virginiana & Persimmon \\
\hline 20 & Equisetum sp. & Horsetail \\
\hline 21 & Euonymus sp. & Winter creeper** \\
\hline 22 & Festuca sp. & Fescue \\
\hline 23 & Fraxinus pennsylvanica & Green ash* \\
\hline 24 & Galium sp. & Bedstraw \\
\hline 25 & Halesia sp. & Silver bell \\
\hline 26 & Hamamelis virginiana & Witch-hazel \\
\hline 27 & Hydrangea quercifolia & Oakleaf hydrangea* \\
\hline 28 & Hypericum frondosum & Golden St. Johnswort* \\
\hline 29 & Hypericum hypericoides & St. Andrew's cross* \\
\hline 30 & Impatiens sp. & Jewelweed \\
\hline 31 & Juglans nigra & Black walnut \\
\hline 32 & Juniperus virginiana & Eastern red cedar* \\
\hline 33 & Liatris squarrosa & Scaly blazing star* \\
\hline 34 & Liquidambar styraciflua & Sweetgum* \\
\hline 35 & Liriodendron tulipifera & Tulip poplar* \\
\hline 36 & Lonicera japonica & Japanese honeysuckle** \\
\hline
\end{tabular}




\begin{tabular}{|c|c|c|}
\hline 37 & Medicago lupulina & Black medick \\
\hline 38 & Microstegium vimineum & Nepal grass** \\
\hline 39 & Panicum virgatum & Swtichgrass \\
\hline 40 & Parthenocissus quinquefolia & Virginia creeper* \\
\hline 41 & Penstemon digitalis & Fox-glove beard-tongue* \\
\hline 42 & Phytolacca americana & Pokeweed \\
\hline 43 & Platanus occidentalis & American sycamore* \\
\hline 44 & Polygonum cespitosum & Smartweed \\
\hline 45 & Polygonum hydropiperoides & Water smartweed \\
\hline 46 & Potentilla indica & Mock strawberry** \\
\hline 47 & Prunus serotina & Black cherry \\
\hline 48 & Rhus aromatica & Gro-low sumac** \\
\hline 49 & Rhus copallina & Winged sumac* \\
\hline 50 & Rhus glabra & Smooth sumac \\
\hline 51 & Rubus argutus & Blackberry \\
\hline 52 & Rudbeckia hirta & Black-eyed susan* \\
\hline 53 & Rudbeckia pinnata & Prairie coneflower* \\
\hline 54 & Rumex crispus & Curled dock \\
\hline 55 & Salix nigra & Black willow \\
\hline 56 & Schizachyrium scoparium & Little bluestem* \\
\hline 57 & Sorghum halepense & Johnson grass** \\
\hline 58 & Sporobolus heterolepis & Prairie dropseed* \\
\hline 59 & Symphoricarpos orbiculatus & Coralberry* \\
\hline 60 & Toxicodendron radicans & Poison ivy \\
\hline 61 & Ulmus alata & Winged elm \\
\hline 62 & Verbesina alternifolia & Wingstem \\
\hline 63 & Vernonia gigantean & Tall ironweed \\
\hline 64 & Viburnum sp. & Rusty blackhaw* \\
\hline 65 & Vitis sp. & Grape \\
\hline
\end{tabular}

*Species on the mitigation planting list

**Exotic invasive species 
APPENDIX D - PLANTING PLAN FOR WHITE OAK CREEK MITIGATION 


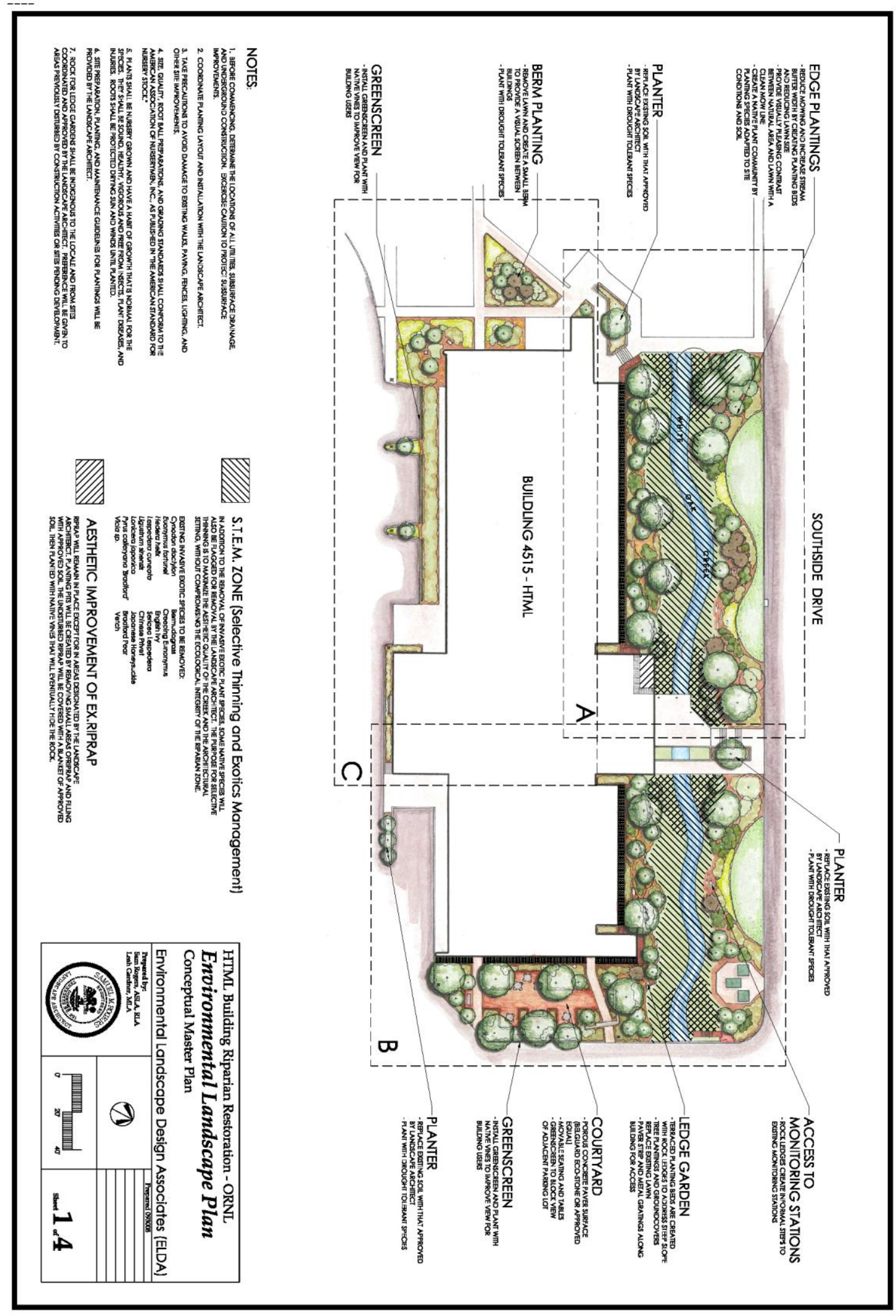




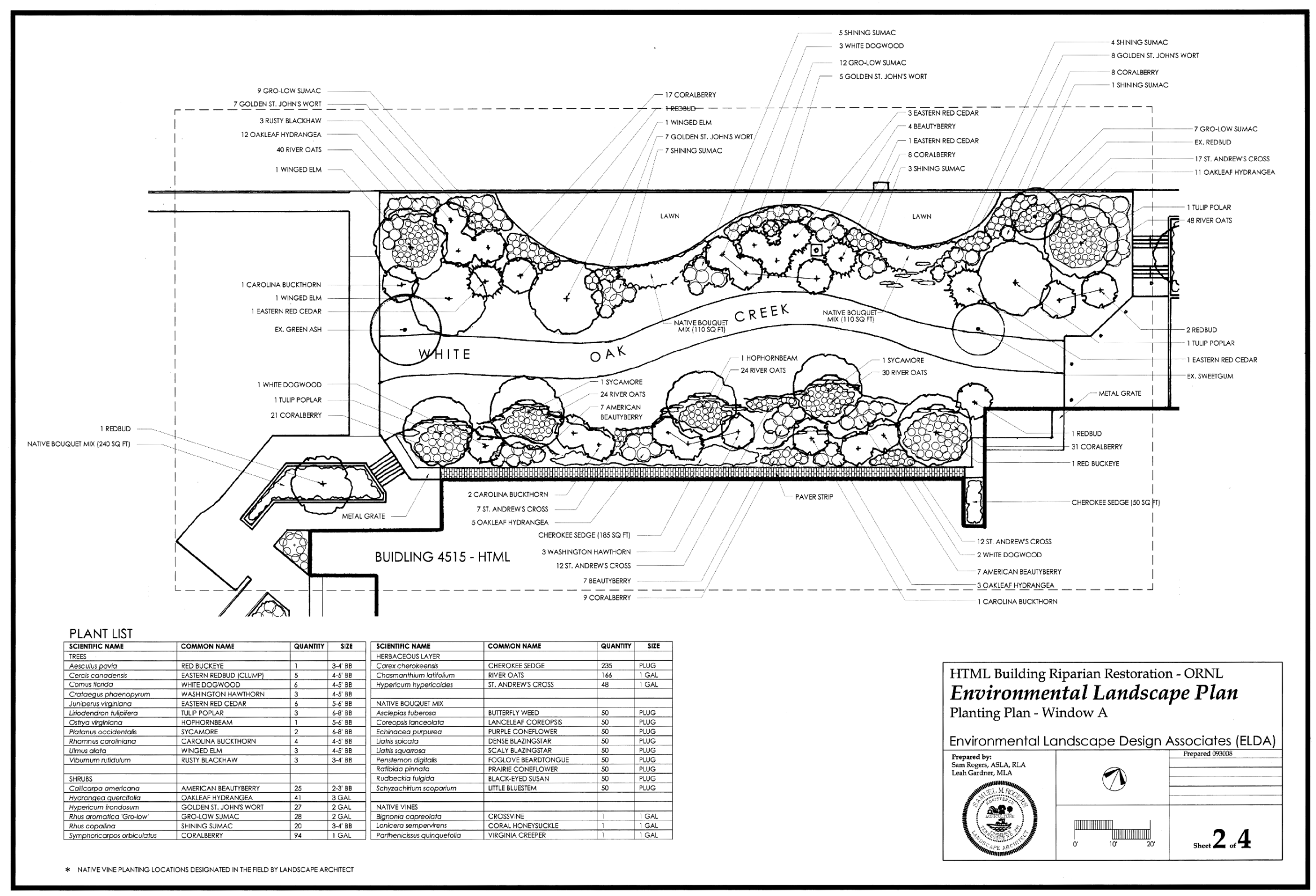




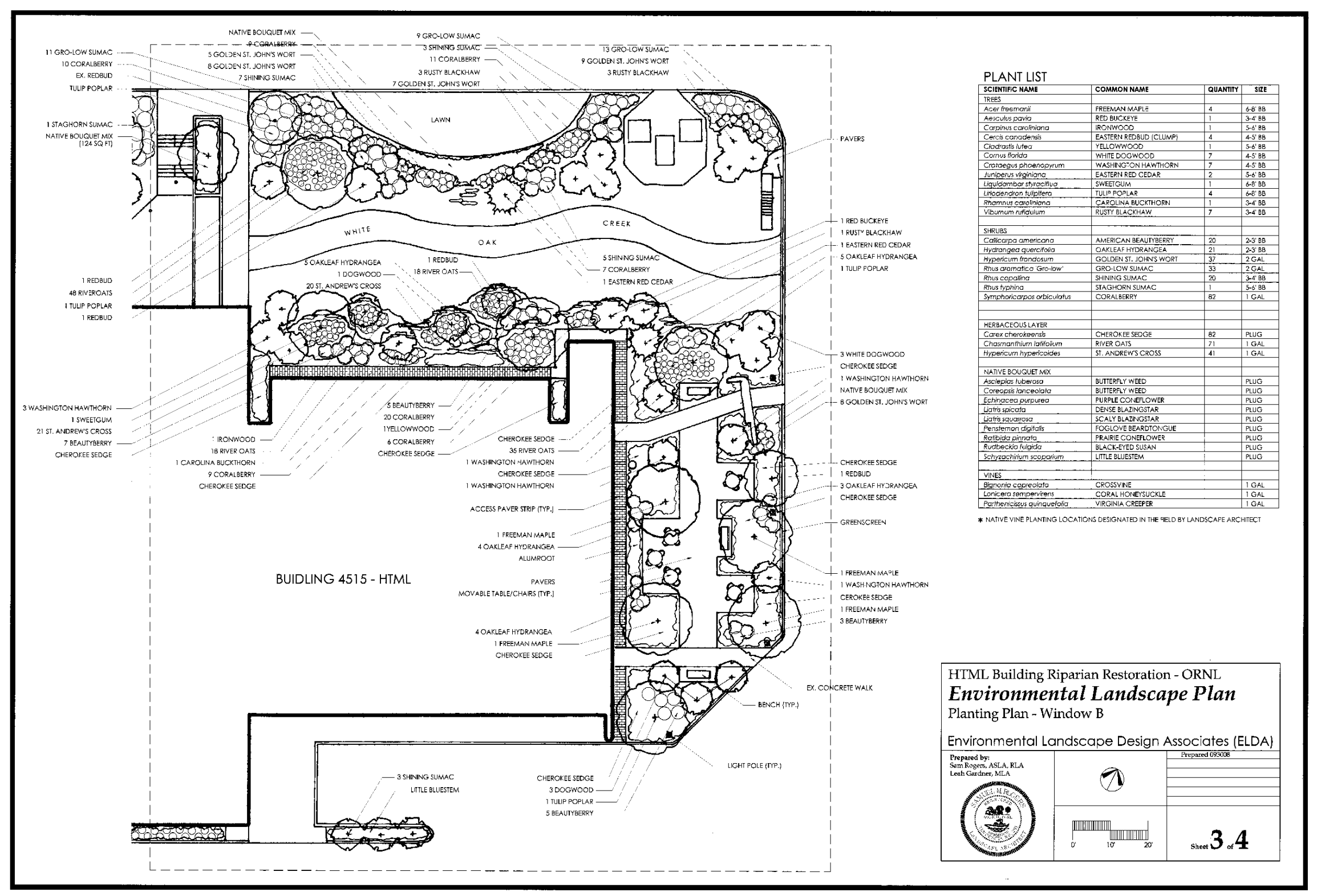




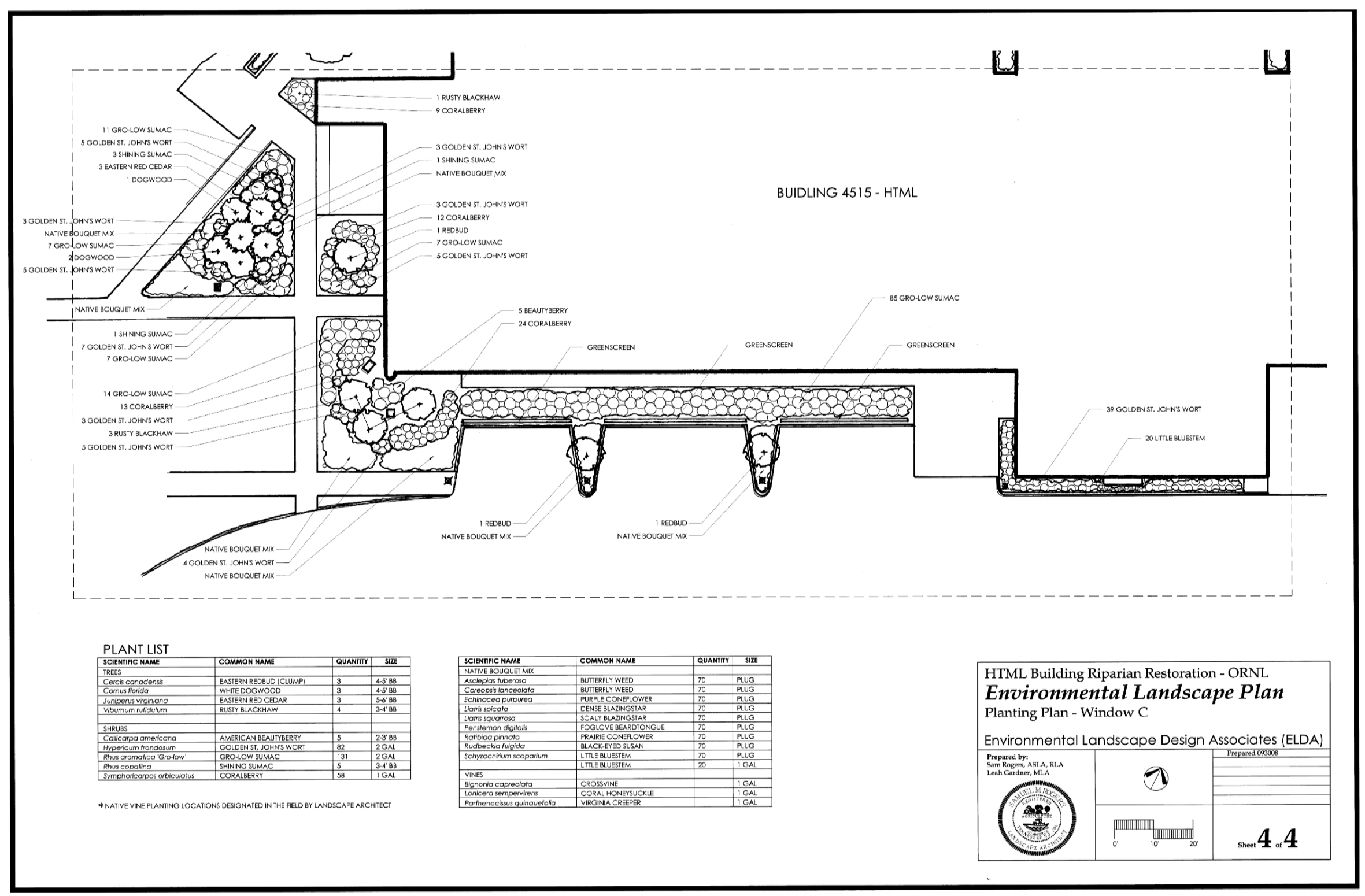

